\title{
Global Connectedness
}

and Local Innovation in Industrial Clusters

EKATERINA TURKINA ARI VAN ASSCHE 
2018s-12

\title{
Global Connectedness and Local Innovation in Industrial Clusters
}

\author{
Ekaterina Turkina, Ari Van Assche
}

\begin{tabular}{c}
\hline Série Scientifique \\
Scientific Series
\end{tabular}

\section{Montréal \\ Avril/April 2018}

(C) 2018 Ekaterina Turkina, Ari Van Assche. Tous droits réservés. All rights reserved. Reproduction partielle permise avec citation du document source, incluant la notice $\mathbb{C}$. Short sections may be quoted without explicit

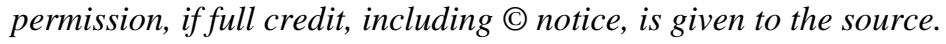

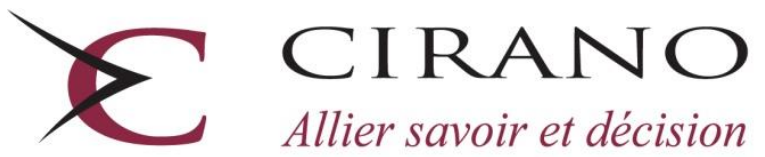

Centre interuniversitaire de recherche en analyse des organisations 


\section{CIRANO}

Le CIRANO est un organisme sans but lucratif constitué en vertu de la Loi des compagnies du Québec. Le financement de son infrastructure et de ses activités de recherche provient des cotisations de ses organisations-membres, d'une subvention d'infrastructure du gouvernement du Québec, de même que des subventions et mandats obtenus par ses équipes de recherche.

CIRANO is a private non-profit organization incorporated under the Quebec Companies Act. Its infrastructure and research activities are funded through fees paid by member organizations, an infrastructure grant from the government of Quebec, and grants and research mandates obtained by its research teams.

\section{Les partenaires du CIRANO}

\section{Partenaires corporatifs}

Autorité des marchés financiers

Banque de développement du Canada

Banque du Canada

Banque Laurentienne du Canada

Banque Nationale du Canada

Bell Canada

BMO Groupe financier

Caisse de dépôt et placement du Québec

Énergir

Hydro-Québec

Innovation, Sciences et Développement économique

Intact Assurance

Investissements PSP

Ministère de l'Économie, de la Science et de l'Innovation

Ministère des Finances du Québec

Mouvement Desjardins

Power Corporation du Canada

Rio Tinto

Ville de Montréal

\section{Partenaires universitaires}

École de technologie supérieure

HEC Montréal

Institut national de la recherche scientifique

Polytechnique Montréal

Université Concordia

Université de Montréal

Université de Sherbrooke

Université du Québec

Université du Québec à Montréal

Université Laval

Université McGill

Le CIRANO collabore avec de nombreux centres et chaires de recherche universitaires dont on peut consulter la liste sur son site web.

Les cahiers de la série scientifique (CS) visent à rendre accessibles des résultats de recherche effectuée au CIRANO afin de susciter échanges et commentaires. Ces cahiers sont écrits dans le style des publications scientifiques. Les idées et les opinions émises sont sous l'unique responsabilité des auteurs et ne représentent pas nécessairement les positions du CIRANO ou de ses partenaires.

This paper presents research carried out at CIRANO and aims at encouraging discussion and comment. The observations and viewpoints expressed are the sole responsibility of the authors. They do not necessarily represent positions of CIRANO or its partners. 


\title{
Global Connectedness and Local Innovation in Industrial Clusters
}

\author{
Ekaterina Turkina, Ari Van Assche*
}

\begin{abstract}
Résumé/Abstract
In today's knowledge economy, clusters are a key driver of a country's competitiveness. Yet a cluster's technological base is now more than ever influenced by constituent firms' actions to tap into distant knowledge sources. Drawing on a social network perspective, and distinguishing between horizontal versus vertical organization-based linkages, we explore the effects of a cluster's connectedness to foreign locations on its innovation performance. We show that improvements in horizontal and vertical connectedness both stimulate a cluster's innovation performance, but that their relative effects vary across cluster types. Innovation in knowledge-intensive clusters disproportionately benefits from enhancements in their constituent firms' horizontal connectedness to foreign knowledge hotspots. Innovation in labor-intensive clusters mostly gains from stronger vertical connections by their firms to central value chain players abroad. We discuss the implications of our findings for research on global knowledge sourcing and cluster upgrading.
\end{abstract}

Mots clés/Keywords: Cluster; Knowledge Sourcing; Connectedness; Network Analysis; Patent

\footnotetext{
* HEC Montréal and CIRANO. Both authors contributed equally to this study. We would like to thank Ram Mudambi, Alain Verbeke, Harald Bathelt, John Cantwell and four anonymous reviewers for their helpful comments. We acknowledge financial support from Canada's Social Sciences and Humanities Research Council. Correspondence: A. Van Assche, Department of International Business, HEC Montréal, Montréal H3T2A7, Canada. Phone: (514)340-6043. E-mail: ari.van-assche@hec.ca.
} 


\section{INTRODUCTION}

One of the most salient features of today's global economy has been the rapid rise in the extent to which firms connect locations. Due to reductions in spatial transaction costs, companies headquartered in one place nowadays develop a broad set of inter-organizational linkages to locations in other countries to gain access to new knowledge, ideas and resources. Vertically, companies connect to foreign suppliers to obtain key inputs needed to produce their goods or services. Horizontally, they set up foreign subsidiaries or develop alliances with foreign firms to tap into pockets of knowledge that are unavailable locally.

The question about why and how firms connect locations has long been a central topic of research in the field of international business. More recently, however, there have been growing calls in the international business community to study the macro-implications of cross-border connections for the local context (Alcacer, Cantwell \& Piscitello, 2016; Cano-Kollmann, Cantwell, Hannigan, Mudambi \& Song, 2016). This is because, when many co-located companies simultaneously fineslice their activities and develop international organization-based linkages, this alters the characteristics of the home region, setting in motion an intrinsic co-evolution of firms and locations (Cano-Kollmann et al. 2016; Cantwell 2009; Cantwell, Dunning \& Lundan, 2010).

This co-evolution concern has received particular attention in studies of industrial clusters (Rugman \& Verbeke, 2013; Li \& Bathelt, 2018). In today's knowledge economy, clusters are considered an exceptionally fertile ground for entrepreneurship, creativity and innovation (Delgado, Porter \& Stern, 2014; Florida, 2002; Porter, 1998). Mobilizing the innovation potential of clusters is thus seen as critical for strengthening a country's international competitiveness. At the same time, the decision of many constituent firms in Silicon Valley and other knowledge clusters to disperse their production and knowledge networks globally has led scholars to question if globalization is altering the viability and value of innovation ecosystems in industrial clusters (Buciuni \& Pisano, 2015; De 
Marchi \& Grandinetti, 2014). Some scholars have raised the concern that the international expansion of firm networks is undermining a cluster's technological edge by eroding key industrial commons such as local know-how and R\&D infrastructure (Buciuni \& Pisano, 2015; Pisano and Shih, 2009). Others have countered that international firm networks can actually be a boon for the local innovation ecosystem by providing constituent firms access to foreign know-how which was previously unavailable (Awate \& Mudambi, 2017; Rugman \& Verbeke, 2003).

In this paper, we focus on the latter argument by investigating both theoretically and empirically how a cluster's connectedness to foreign locations through organization-based linkages affects its local innovation performance. Building on the knowledge-based view of the cluster, we take as a starting point that clusters are not self-sufficient in terms of the knowledge capabilities they draw upon (Wolfe \& Gertler, 2004). Rather, they rely on their firms' linkages to companies in other countries to bring in new knowledge that can help sustain the health of their local innovation system (Bathelt, Malmberg \& Maskell, 2004; Cano-Kollmann et al. 2016). Owen-Smith \& Powell (2004), for example, show in the case of the Boston biotechnology industry that new knowledge was often acquired through strategic international partnerships. Hannigan, Cano-Kollmann \& Mudambi (2015) illustrate that in recent decades innovation activities in Detroit's automotive sector have thrived due to their increased connectedness to other global centers of excellence. Scalera, Perri \& Hannigan (2018) find that cross-border linkages provide constituent firms with more valuable external knowledge than subnational connections.

This emerging line of research on global connectedness and local outcomes has not yet addressed two key issues. First, little is known about the type of international linkages that are most effective in stimulating an industrial cluster's local innovation performance. To our knowledge, only the study by Lorenzen \& Mudambi (2013) distinguished between organization-based and person-based global linkages, and analyzed the different ways in which such connections allow local industries 
to hook onto the global innovation system. Questions remain, however, as to whether different types of organization-based connections should be treated symmetrically, particularly given that knowledge-seeking and efficiency-seeking linkages are known to lead to the transfer of different knowledge (Giroud \& Scott-Kennel, 2009). Second, research is needed to determine if clusters that specialize in different activities benefit from the same types of international organization-based connections to boost their local innovation system. Clusters in emerging markets, for example, specialize in less knowledge-intensive activities than their developed-country counterparts (Mudambi, 2008). It is thus legitimate to question if a specific type of organization-based connection has the same effect on innovation in different types of clusters.

In this paper, we delve deeper into these two issues by building a theory of the "global cluster network". This theory treats industrial clusters as nodes which are rooted in a global network of clusters, and which are connected to each other through two types of organization-based linkages: "horizontal" partnership linkages between firms specialized in similar value chain activities, and "vertical" buyer-supplier connections between companies specialized in different value chain stages. We then combine insights from international business theory, economic geography and social network analysis to evaluate how a cluster's relative position in the global cluster network relates to (1) the type of value chain activities in which it specializes, and (2) the type of international organization-based linkages that disproportionately strengthens local innovation.

Our framework allows us to make two key theoretical contributions. First, we develop a new typology of four stylized cluster archetypes based on their multiplex embeddedness in the global cluster network. Second, we construct novel hypotheses that link a cluster's knowledge intensity to the type of cross-border linkages which its constituent MNEs should build to optimally boost local innovation performance. 
To validate our theoretical predictions, we take advantage of a comprehensive dataset that we handcollected on the network of international linkages across 154 clusters located in three knowledgeintensive industries (aerospace, biopharma and ICT) during the period 2002-2014. By linking our network data with information on the industry-specific patenting activities in clusters, we are able to establish a far richer empirical relation between a cluster's international connectedness and its local innovation performance.

The paper is organized as follows. Section 2 presents an overview of the relevant literature and develops our main hypotheses. Section 3 explains our data collection procedure. Section 4 contains the empirical analysis and discusses the results. Section 5 outlines the implications of our findings for our understanding of clusters and provides concluding remarks.

\section{THEORY DEVELOPMENT}

\section{Towards a global network view of clusters}

Clusters have long been recognized as engines of regional economic performance. Defined as "a geographically proximate group of inter-connected companies and associated institutions in a particular field, linked by commonalities and complementarities" (Porter, 1998), numerous empirical studies have shown that clusters generate greater entrepreneurship, innovation, and job creation compared to other locations (Delgado, Porter \& Stern, 2010; Delgado et al., 2014).

Scholars have traditionally focused on the presence of spatially mediated knowledge externalities to explain the superior performance of clusters. The conventional rationale for localized knowledge spillovers is that many processes of knowledge creation are spatially sticky, requiring direct and repeated face-to-face contact (Jaffe, Trajtenberg \& Henderson, 1993; Storper \& Venables, 2004). For firms, co-locating with similar and related companies thus has the advantage that it can boost 
collective learning processes through frequent opportunities for formal and informal exchanges (Maskell \& Malmberg, 1999).

Recent studies point out, however, that geographical proximity is not a sufficient condition for firms to accrue localized knowledge externalities (Boschma, 2005). Knowledge spillovers rarely spring from unplanned, random interactions between co-located players as should be expected if it were merely "in the air" (Giuliani, 2007). Rather, they emerge from purposeful and selective network linkages that firms develop with other co-located actors (Cantwell \& Mudambi, 2011; Owen-Smith \& Powell, 2004; Singh, 2005). Giuliani \& Bell (2005) indeed show that companies in a Chilean wine cluster differed significantly in their network of local linkages, with some well connected to other local firms and others acting in isolation. They find that peripheral inclusion in the local network hampers a firm's learning and innovation opportunities. Boschma (2005) therefore suggests that, besides geography, four other dimensions of proximity (cognitive, social, organizational and institutional) explain the likelihood that firms create an inter-organizational network linkage.

Other studies point out that a purely local view of clusters ignores the importance of international linkages for a cluster's performance. Many cluster firms deliberately establish international linkages to other clusters to avoid technological lock-in and to tap into pockets of complementary knowledge and resources that are unavailable or more expensive locally (Awate \& Mudambi, 2017; Bathelt et al., 2004; Lorenzen \& Mudambi, 2013). Therefore, clusters are not self-sufficient in terms of the knowledge and resource base they draw upon, and it is therefore limiting to consider them as isolated systems (Wolfe \& Gertler, 2004). Rather, a better way to represent a cluster is as a node which is embedded in a larger "global cluster network" of exchanges that spans multiple clusters (Li \& Bathelt, 2018; Turkina, Van Assche \& Kali, 2016). Successful clusters are those in which firms are effective at building a broad network of organization-based linkages for accessing 
relevant foreign knowledge capabilities (Bathelt et al., 2004; Boschma \& Ter Wal, 2007; Wolfe \& Gertler, 2004).

\section{Network embeddedness and cluster performance}

We take the global cluster network as a starting point and rely on insights from the study of interorganizational networks to investigate how a cluster's structural embeddedness in the network affects its ability to access knowledge from foreign locations, thus enhancing its economic returns.

Scholars have paid growing attention to social network analysis when studying the performance implications of a firm's inter-organizational relations. Building on ideas developed in the analysis of inter-personal networks, researchers have proposed that firms can be considered as nodes embedded in webs of inter-organizational relations, and have investigated the antecedents and consequences of their embeddedness in these networks (e.g., Gulati, 2007). Several researchers have emphasized the structural properties of networks (e.g., Burt, 1992), while others have focused on the characteristics of inter-organizational ties (e.g., Granovetter, 1985). Most relevant to our study, however, a third set of studies depict inter-organizational relations as conduits of network resources that shape firm performance. Gulati (1999) and Lavie (2006) define network resources as the tangible and intangible assets that reside outside of a firm's boundaries but that can potentially be accessed through inter-organizational connections. They posit that these network resources can directly contribute to corporate performance by supplementing a firm's own resources with knowledge that is unavailable internally (see also Dyer and Singh, 1998).

International business scholars have added a geographical dimension to the picture by pointing out that multinational firms often strategically locate their subsidiaries in foreign countries to enrich their network resources. Cantwell (1989) notes that technology differs across locations, and that firms aim to supplement their local technologies by expanding internationally to tap into new and diverse knowledge pockets. In that case, MNE subsidiaries are simultaneously embedded in two 
networks which provide access to external knowledge and information: (1) a global network that is comprised of the headquarter and other subsidiaries, and (2) a local network of host country firms (Almeida and Phene, 2004; Andersson and Forsgren, 2000; Asakawa, Park, Song \& Kim, 2018; Meyer, Mudambi \& Narula, 2011). This notion of dually embedded subsidiaries has led to an influential literature on the location of competence-creating subsidiaries and the use of locations as a source of competitive advantage for firms (Cantwell and Mudambi, 2005). ${ }^{2}$

In the above-mentioned studies, the firms or subsidiaries are the active agents, with locations deemed an exogenous force. Several recent studies have qualified this belief. If many cluster firms simultaneously attempt to strengthen their network resources by building linkages to firms or subsidiaries in foreign locations, this not only enhances the performance of the individual firms, but also improves the internal dynamism of the entire cluster (Lorenzen \& Mudambi, 2013). In other words, the very process of many firms accessing foreign knowledge through international business networks alters the characteristics of locations, setting in motion an intrinsic co-evolution of firms and locations (Cano-Kollmann et al., 2016; Cantwell et al., 2010; Rugman \& Verbeke, 2003). In parallel to the inter-organizational networks literature, one can thus expect that a cluster's embeddedness in the global cluster network affects its network resources, i.e. the tangible and intangible assets that reside outside of a cluster's geographical borders which it can access through connections to foreign clusters (Alcacer et al., 2016).

To our knowledge, few studies have systematically examined the link between a cluster's structural embeddedness in the global cluster network and its local innovation performance. A couple of studies have documented the growing international connectedness of a specific cluster (Awate \& Mudambi, 2017; Hannigan et al., 2015; Lorenzen \& Mudambi, 2013), yet they have not considered

\footnotetext{
${ }^{2}$ Other studies have studied how a multinational firm's embeddedness in the local network affects the geographical scope of its subsidiaries (Iurkov \& Benito, 2018).
} 
the structure and configuration of the entire network when measuring the overall embeddedness of a cluster. In this paper, we aim to add to this literature by developing a new approach based on social network analysis to analyze a cluster's s global network embeddedness.

\section{Network centrality}

Social network scholars have developed numerous measures to identify an actor's structural embeddedness in a network (Wasserman and Faust, 1994). It is beyond the scope of this paper to provide a complete overview of the work done in this area, so we restrict ourselves to the discussion of two common measures: degree and eigenvector centrality (see Zaheer, Gözübüyük \& Milanov (2010) for an overview in the field of strategy).

Degree centrality is a basic measure that captures the number of linkages that an actor has with other actors (Freeman, 1979). An actor with high degree centrality is directly connected with many actors, and is thus considered to have access to a wide variety of knowledge that is unavailable internally (Wasserman and Faust, 1994). This measure is favored by many empirical studies since it only requires information about an actor's direct number of relations.

Eigenvector centrality is a richer measure that takes into account that an actor's network resources not only depends on the knowledge that can be accessed through the actor's direct ties, but also on its partners' ability to obtain knowledge from elsewhere in the network (Ahuja, 2000; Powell, Koput \& Smith-Doerr, 1996). Therefore, the measure considers the configuration of the entire network and gives a higher weight to ties to partners which are central in the network (Bonacich, 1987). In this respect, an eigenvector central actor is considered to have higher network resources since it has better access to key knowledge from elsewhere in the network through both its direct and indirect ties (Podolny, 2001; Soh, Mahmood \& Mitchell, 2004; Stuart, Hoang \& Hybels, 1999). In contrast, an actor with a low eigenvector centrality can only tap into limited knowledge from the network through its portfolio of international linkages. In this paper, we will rely on this measure 
and use a new hand-collected dataset that captures a large network of formal linkages between clusters to operationalize it empirically.

\section{Linkage heterogeneity}

A shortcoming of centrality measures is that they ignore the heterogeneity in linkage types that clusters use to access external knowledge capabilities (Lorenzen \& Mudambi, 2013). It has been widely acknowledged in international business studies that firms build a variety of international linkages with other companies, which lead to the transfer of different knowledge capabilities (Giroud \& Scott-Kennell, 2009). Standard centrality measures ignore these differences, implicitly assuming that all linkage types are equivalent in terms of their ability to access knowledge.

Terminology varies considerably across studies, but international business and economic geography scholars generally categorize organization-based linkages into two main groups: horizontal versus vertical linkages (Giroud \& Scott-Kennell, 2009; Malmberg \& Maskell, 2006; Mesquita \& Lazzarini, 2008). Horizontal linkages are defined as collaborative relations between firms that are located in the same value chain portion (i.e. task) or industry segment, which are built to access lateral "intra-task" knowledge competencies (e.g. technology sharing agreements, coproduction agreements). Vertical linkages are hierarchical buyer-supplier relations between firms specializing in different stages of the same value chain, providing access to "inter-task" knowledge competencies.

This categorization should not be confounded with that in studies on intra-MNE knowledge flows which treats lateral linkages between subsidiaries as horizontal and headquarter-subsidiary ties as vertical (Ghoshal, Korine \& Szulanski, 1994). Indeed, in this paper, we focus on the stratification of firms along the value chain to distinguish between horizontal versus vertical linkages, not on firms' hierarchical positions within the multinational firm. 
Horizontal linkages have been a primary focus in studies of global knowledge sourcing, whereas vertical linkages have been at the center of global value chain governance studies. The global knowledge sourcing literature has studied the motives of firms to build horizontal knowledgegenerating linkages to foreign knowledge partners. The starting point in these studies is that knowledge-intensive firms constantly need to search for useful new knowledge combinations to catalyze their idiosyncratic knowledge capabilities (Cantwell, 1989; Galunic \& Rodan, 1998), but that the relevant knowledge sources to do so are widely distributed across the globe (Cantwell \& Janne, 1999; Chung \& Yeaple, 2008). Therefore, knowledge-intensive firms deliberately set up connections to foreign locations to reinforce learning processes associated with accessing complementary knowledge pockets (Cantwell and Santangelo, 1999). They can do so by setting up intra-firm linkages to competence-creating subsidiaries (Almeida \& Phene 1994; Cantwell \& Mudambi, 2005) or by developing inter-firm partnerships (Powell et al. 1996; Roijakkers \& Hagedoorn, 2006). These connections not only provide access to technological capabilities embedded in their partners, but also to the knowledge capabilities embedded in the partner cluster's environment (Cantwell \& Mudambi, 2011; Inkpen, 1998). Once new knowledge is tapped into, companies use reverse knowledge transfer to enhance the parent firm's innovation in its home cluster through combinative knowledge generation (Berry, 2014; Chung \& Yeaple, 2008).

The global value chain governance literature, then again, studies how knowledge-intensive "lead" firms orchestrate their portfolio of vertical linkages with foreign suppliers that specialize in complementary value chain tasks, and how this affects knowledge transfers between global value chain actors (Gereffi, Humphrey \& Sturgeon, 2005; Kano, 2018; Mudambi 2008). To develop a final value proposition, lead firms need to combine their own idiosyncratic knowledge capabilities in core value chain activities (e.g. R\&D and marketing) with other tasks that are conducted by distinct value chain partners. They often select foreign suppliers to take advantage of comparative advantage forces, which leads to the establishment of international buyer-supplier linkages 
(Mudambi, 2008; Sturgeon, Van Biesebroeck \& Gereffi, 2008). At the same time, they attempt to improve the value chain's overall efficiency by funneling relevant knowledge from different parts of the chain to certain suppliers so as to strengthen their production capabilities (Dhanaraj \& Parkhe, 2006; Kano, 2018). For example, to improve the production quality of their suppliers, lead firms often share production techniques and quality insurance methods, or assist with technology acquisition (Crespo \& Fontoura, 2007; Javorcik, 2008). Depending on the governance structure of the value chain (Humphrey \& Schmitz, 2002), these actions lead to the transfer of intra-task knowledge capabilities which help suppliers to migrate up the value chain towards higher value activities (Alcácer \& Oxley, 2014; Pietrobelli \& Rabellotti, 2011).

A comparison of the nature and the mechanisms behind the two types of organization-based linkages suggests that they provide access to distinct knowledge capabilities, and should be treated so when studying a cluster's global network embeddedness. Indeed, they are built to different types of locations, are used to transmit different types of knowledge and capabilities, and have a different degree of efficiency for transferring knowledge. Following Shipilov (2012), we thus posit that the global cluster network should be treated as a multiplex network where the same set of nodes are linked to one another by multiple types of ties which each are able to transfer certain types of knowledge and information. ${ }^{3}$ In that case, the global cluster network can be broken up into two sub-networks which each specialize in the transmission of certain types of knowledge: a horizontal sub-network that is key for obtaining intra-task knowledge competencies and a vertical sub-network that is central for receiving inter-task knowledge competencies. In the remainder of this section, we use these insights to make two theoretical contributions: (1) to develop a new typology of four

\footnotetext{
${ }^{3}$ Strategy scholars use this concept to investigate how distinct types of network ties differentially affect the formation of strategic alliances (Gulati \& Westphal, 1999) and the acquisition of firm capabilities (Mahmood et al., 2011; McEvily \& Marcus, 2005).
} 
stylized cluster archetypes; (2) to derive novel predictions how a change in a cluster's relative position in the global network affects its innovation performance.

\section{Cluster Archetypes}

The global cluster network reveals important information about clusters' relative positions in an industry that goes beyond simple categorizations based on the development level of the country in which it is located or its technology level. A cluster's multiplex position in the network exposes information about its pattern of knowledge search which, in turn, provides insights about the type of activities in which it specializes (Podolny, 2001; Awate \& Mudambi, 2017). Take a cluster with a high eigenvector centrality in the horizontal sub-network as an example. We can expect it to specialize in knowledge-intensive activities since it is in this type of activities that competition pushes firms to seek lateral intra-task knowledge competencies in distant locations (Berry, 2014; Cantwell, 1989). ${ }^{4}$ A cluster with a high eigenvector centrality in the vertical sub-network, then again, specializes in a key value chain stage since it is companies that concentrate on this type of activities that disproportionately develop buyer-supplier linkages to foreign clusters which specialize in complementary value chain tasks. These insights allow us to develop a new typology of four stylized cluster archetypes based on their differential embeddedness in the multiplex network (see figure 1).

\section{[Figure 1 about here]}

Globally embedded cluster. This cluster archetype is central in both the horizontal and the vertical linkage sub-networks, allowing it to rapidly access both intra-task (horizontal sub-network) and inter-task knowledge competencies (vertical sub-network). Clusters whose operations are arranged around knowledge-intensive OEM activities fit in this category. On the one hand, flagship MNEs

\footnotetext{
${ }^{4}$ We do not say here that labor-intensive clusters (peripheral in the horizontal sub-network) do not have horizontal linkages. Rather, they have fewer and often with other clusters that are relatively peripheral in the horizontal sub-network.
} 
in an OEM cluster are known to build pipelines to other knowledge-intensive clusters that are central in the horizontal sub-network (e.g. R\&D clusters and other OEM clusters), which allow them to tap into the required intra-task knowledge to support their $R \& D$ and/or marketing activities. On the other hand, these same flagship MNEs are also connected to other central clusters in the vertical sub-network in their efforts to orchestrate the production of the necessary subassemblies and subsystems for their products.

Horizontally embedded cluster. This cluster archetype is central in the horizontal sub-network, but peripheral in the vertical sub-network. Clusters specialized in $R \& D$ activities or in other knowledge-intensive support services fit in this quadrant. Their constituent MNEs build crossborder collaborations with peers in other central clusters in the horizontal sub-network to develop and support their knowledge creation capabilities. They are peripheral, however, in the vertical subnetwork since their activities do not require them to collaborate extensively with upstream and downstream firms located in vertically central clusters.

Vertically embedded cluster. This cluster type has a central position in the vertical sub-network, but is peripheral in the horizontal sub-network. Supplier clusters in emerging markets which focus on the labor-intensive assembly of components or subassemblies fit in this quadrant. They have strong buyer-supplier linkages to flagship MNEs in OEM clusters, positioning them centrally in the vertical sub-network. At the same time, since they focus on less knowledge-intensive activities, they do not systematically collaborate with similar firms in horizontally central clusters to obtain intra-task knowledge capabilities (Mudambi, 2008).

Peripheral cluster. This cluster type is peripheral in both the horizontal and vertical sub-network. Clusters that specialize in labor-intensive activities which are also of a lower tier in the supply chain fit in this category. Since they focus on less knowledge-intensive activities, they are not connected 
to horizontally central clusters. And since they focus on lower-tier value chain activities, they are not connected to vertically central clusters.

\section{Hypothesis Development}

The structural positions of clusters evolve over time and we can study such network dynamics to evaluate how a change in a cluster's embeddedness in the global cluster network affects its local innovation performance. For this purpose, we focus on the distinction between knowledgeintensive clusters (central in the horizontal sub-network) and labor-intensive clusters (peripheral in the horizontal sub-network).

The knowledge intensity of a cluster's activities characterizes the type of external network resources it needs to further catalyze its local innovation performance. We argue here that an improvement in access to intra-task knowledge capabilities disproportionately catalyzes innovation in knowledge-intensive clusters compared to labor-intensive clusters. Knowledge-intensive clusters benefit much more from an extensive and exploratory search for competencies across the distribution of intra-task knowledge that is dispersed in the global cluster network than laborintensive clusters (Cantwell \& Mudambi, 2011). Extending this search to more promising areas in the network by improving centrality in the horizontal sub-network should thus lead to a particularly large improvement in local innovation for knowledge-intensive clusters.

It is important to point out that innovation in labor-intensive activities can also benefit from improved centrality in the horizontal sub-network, but not to the same extent as for knowledgeintensive activities. Knowledge diversity is less necessary in activities where knowledge composes a smaller portion of value added (Mudambi and Santangelo, 2016). Firms which specialize in more standardized value chain activities tend to compete more on quality, cost, or other less technical dimensions, and less on advancing technological knowledge (Chung \& Alcacer, 2002). As a result, 
improvements in access to intra-task knowledge capabilities only leads to a relatively limited improvement in innovation in labor-intensive clusters. This leads to our first hypothesis:

Hypothesis 1: An increase in a cluster's centrality in the horizontal sub-network leads to a larger improvement in innovation performance for knowledge-intensive clusters than for labor-intensive clusters.

Improved access to intra-task knowledge capabilities, then again, disproportionately improves innovation in labor-intensive clusters compared to knowledge-intensive clusters. Vertical linkages are a key catalyst of innovation in labor-intensive clusters (Alcacer \& Oxley, 2014; Giuliani, Pietrobelli \& Rabellotti, 2005; Pietrobelli \& Rabellotti, 2011). Peripheral clusters use the development of vertical linkages as a point of entry into global value chains (Mudambi, 2008). Established supplier clusters, then again, can obtain access to superior inter-task knowledge capabilities by building international linkages to stronger value chain players, which it can use to upgrade its value chain activities, improve its innovation performance, or both (Pietrobelli and Rabellotti, 2011). As a result, an improvement in centrality in the vertical sub-network can lead to significant improvements in innovation in labor-intensive clusters.

Once again, this is not to say that improvements in a cluster's centrality in the vertical sub-network cannot stimulate innovation in knowledge-intensive clusters. For firms in knowledge-intensive clusters, collaborating with better foreign value chain partners can free up resources that they can invest in higher-value activities such as R\&D, improving its innovation capabilities (Farrell, 2005; Van Assche, 2017). The effect on innovation, however, is expected to be relatively smaller than for labor-intensive cluster, thus leading to the following hypothesis:

Hypothesis 2: An increase in a cluster's centrality in the vertical sub-network leads to a larger increase in innovation for labor-intensive clusters than for knowledge-intensive clusters. 


\section{NETWORK DATA}

To test our hypotheses, we take advantage of a longitudinal dataset that we have hand-collected on formal linkages between a network of cluster firms in three knowledge-intensive industries: Aerospace, Biopharma and ICT.

The three industries share several characteristics. ${ }^{5}$ First, their production processes rely on a combination of knowledge-intensive and labor-intensive activities (Niosi \& Zhegu, 2005). Second, production requires intensive formal inter-firm collaboration. On the one hand, companies form inter-firm partnerships with other firms to pool resources and benefit from economies of scale (Dussauge \& Garrette, 1995; Roijakkers \& Hagedoorn, 2006; Sturgeon, 2003). On the other hand, the industry is characterized by a high rate of subcontracting along the supply chain (Arora, Fosfuri \& Gambardella, 2001; Niosi \& Zhegu, 2005). Third, the industries exhibit high degrees of spatial clustering (Niosi \& Zhegu, 2005; Sturgeon, 2003). Fourth, all three industries are characterized by high rates of innovation, elevated R\&D expenditures and significant patenting (Arora et al., 2001; Niosi \& Zhegu, 2005).

\section{Network data collection procedure}

We used a three-step procedure to collect our global cluster network data (see Turkina et al. (2016) for more details). In a first step, we used information from the European Cluster Observatory, U.S. Cluster Mapping Project, Canadian Cluster Database and Mexico's INADEM/INEGI to identify for each industry separately the most important clusters in North America and Greater Europe. Specifically, we used a location quotient (LQ) approach to identify the most important clusters (Delgado et al., 2014). ${ }^{6}$ LQ computes the industry's share of regional employment as compared to

\footnotetext{
${ }^{5}$ While these commonalities highlight the appropriateness of focusing on these industries to test our theoretical proposals, we will show in section 5 that they do not imply that there is a lack of variation in the data to conduct our empirical analysis.

${ }^{6}$ Lack of data on cluster activities in Asian and Latin American regions has prevented us from including these regions in our database.
} 
the industry's share of employment across North America and Greater Europe. ${ }^{7}$ If the LQ of a cluster is larger than 1 in a specific industry, we identified it as a potential cluster since there is a higher than average agglomeration of industry-specific employment in that region. We have added to this list clusters in developing countries with a small LQ in 2002-2005, but which showed significant growth of LQ over the time span of our sample.

Initially, in the US we considered Economic Areas, in Europe we considered Nuts II regions. In Canada and Mexico the data were available at provincial level. For each area that we identified as a potential cluster, we next researched whether there exists a formal cluster organization that groups all the major decision makers in the specific sector, including companies, educational and research institutions, associations and unions. The identification of such formal cluster organizations is important since it provides valuable information about the geographical boundaries of the cluster. For cluster that extended across multiple economic regions, we grouped them together as one cluster. This first step provided us with a sample of 56 clusters in Aerospace, 51 clusters in Biopharma and 47 clusters in ICT. The names of the clusters are listed in Table 1. Following the FTSE country classification, we have categorized the clusters into those in developed countries and those in emerging markets (advanced emerging, secondary emerging and frontier).

\section{[Table 1 about here]}

In a second step, we identified for each cluster the list of firms present during each of the three time periods $2002-2005,2006-2009$ and $2010-2014 .^{8}$ There is no single data source that identifies the list of firms present in the various clusters of our sample, and we therefore drew on various webbased resources to compile our list. Part of this information was taken from the cluster

\footnotetext{
${ }^{7}$ We have recalculated the LQs so that the denominator measures the industry's share of employment in North America and Greater Europe combined.

${ }^{8}$ Before 2002, many indicators in the cluster observatories have missing values. Concerning the threeperiod operationalization, it is common in social network analysis to use time-periods of three to five years as it is difficult to trace the multitude and multiplicity of annual linkages (Coleman, 1988; Burt, 1992).
} 
observatories, which contains reports on different cluster events in which companies participated. We validated this list and complemented it by consulting various cluster resources such as formal cluster websites and public reports. In total, we identified 7,902 separate firm-period combinations.

In a final step, we used public reports and articles to carefully map for each cluster firm its formal linkages with other firms for each time period. As is common in social network analysis, we measured linkages on a binary scale: 0 for the absence and 1 for the presence of a formal relationship. To increase our confidence in the validity of the linkages, we included only those ties that appeared in at least two distinct data sources.

We categorized linkages along two dimensions. First, we distinguished across geography. We identified a linkage to be local if there was a formal relationship between firms located within the geographical boundaries of the same cluster, regional if the relation was between firms located in different clusters within the same country, and international if the link was between firms located in clusters from different countries.

Second, we differentiated between two types of inter-organizational linkages: vertical and horizontal linkages.

- Vertical linkage. To establish the presence of a vertical linkage between two firms, we focused on the existence of a buyer-supplier relation. Specifically, we started off by searching if a company features on the approved supplier list (ASL) of another firm and is in one of the clusters in our dataset. In a second step, we searched various online documents and sources to identify additional buyer-supplier connections.

- Horizontal linkage. We consider two firms to have a horizontal linkage if they have a formal partnership such as a joint R\&D program, a joint venture (equal, majority or 
minority), or a formal training partnership. ${ }^{9}$ To gather this information, we used company reports and websites, and supplemented it with information from news articles, and other credible on-line information.

We also collected data on intra-firm linkages between subsidiaries of the same company. Firms are considered to have an intra-firm linkage with another entity if they both have the same global ultimate owner. To identify these linkages, we first relied on official company reports to identify the list of a firm's subsidiaries that are in the clusters included in our database. Next, we verified and complemented this information using Orbis, adding those subsidiaries which are owned entirely by a global ultimate owner. Since it is difficult to determine whether an intra-firm linkage is horizontal or vertical of nature (Alfaro \& Charlton, 2009), we do not use intra-firm linkages to test our hypotheses, but rather use it as a control variable.

In total, our dataset consists of 35,181 observations of local linkages and 8,880 of trans-local linkages across 154 clusters during the three time periods 2002-2005, 2006-2009 and 2010-2014. About $75 \%$ of the linkages came from official company reports, with the remaining $25 \%$ attained from on-line information. While we cannot claim that our dataset is complete, we are confident that we have assembled the most comprehensive longitudinal database of linkages between cluster firms in the Aerospace, Biopharma and ICT industry to date. We checked for the robustness of the constructed network by testing whether it is a scale free. The test was affirmative, implying that even if there are missing linkages, there is a high likelihood that it will follow the general pattern of the network and its introduction will not significantly change the properties of the network. ${ }^{10}$

\section{From Local to Global}

\footnotetext{
${ }^{9}$ We treat joint ventures as a partnership linkage since it requires the firm to coordinate its decisions with a partner. If a joint venture acts as a supplier, however, it is also reflected as a vertical relationship. Fullyowned subsidiaries are considered an intra-firm linkage since the firm is a sole decision-maker that does not coordinate its efforts with another firm.

${ }^{10}$ Node degree distributions of our networks approximate a power law distribution.
} 
Table 2 shows that international linkages constitute a significant portion of all linkages. In Aerospace, international linkages consisted of $4.73 \%$ of all partnership linkages, $7.18 \%$ of all buyer-supplier linkages, and $66.12 \%$ of all intra-firm linkages during the period $2010-2014$. In the highly global ICT sector, international linkages consisted of $8.31 \%$ of all partnership linkages, $39.45 \%$ of all buyer-supplier linkages and $80.77 \%$ of all intra-firm linkages. Furthermore, the table highlights that international linkages have consistently grown across all linkage types and across all industries over our sample period.

\section{[Table 2 about here]}

Table 2 highlights several trends which are in line with the emergence of global value chains. In all three industries, there is evidence of an increase in the share of international buyer-supplier linkages between the period 2002-2005 and the period 2010-2014. In aerospace, for example, the portion of international buyer-supplier linkages increased from $5.63 \%$ in $2002-2005$ to $7.18 \%$ in 2010-2014. This is largely due to the disappearance of local buyer-supplier linkages. In all three industries, we find that local buyer-supplier linkages have declined between $8 \%$ and $16 \%$ over the sample period. These local linkages have been replaced by international linkages between clusters in the same country as well as by regional linkages.

The share of international partnership linkages has followed an opposite trend, however, declining in all three industries. This is largely because local partnership linkages have grown at a faster pace than international partnership linkages. In aerospace, for example, international partnership linkages have grown 5.18\% in 2010-2014, but local linkages have grown $11.60 \%$. In other work, we have attributed this to the fact that clusters over time have started specializing in fine-grained slices of global value chains rather than in entire industries (Turkina et al., 2016).

In sum, descriptive statistics suggest that international linkages are a significant part of a cluster's total linkages. At the same time, there are important variations in trends across linkage type, with 
vertical buyer-supplier linkages becoming relatively more international and horizontal partnership linkages becoming relatively more local.

\section{METHODOLOGY}

The goal of our empirical analysis is to analyze if a dynamic change in a cluster's multiplex embeddedness in the global cluster network affects its local innovation performance, and whether this effect varies depending on a cluster's knowledge intensity. For this purpose, we first develop a methodology to categorize the cluster into the four proposed archetypes. Next, we use regression analysis to study if dynamics in a cluster's structural embeddedness is related differentially to its innovation performance depending on the type of cluster.

\section{Archetype identification}

To identify a cluster's archetype, we will first study a cluster's combined embeddedness in both the horizontal "partnership" and vertical "buyer-supplier" sub-networks. To do so, we for each cluster $i$ in industry $k$ and period $t$ calculate its eigenvector centrality in both sub-networks separately, where we define eigenvector centrality of a cluster $i$ as the linear combination of the eigenvector centrality of its neighbors $j$ :

$C_{i k t}=\frac{1}{\lambda} \sum_{j=1}^{n} A_{i j k t} C_{j k t}$

where $\lambda$ is a constant and $A_{i j k t}$ takes a value of one if there is a linkage between cluster $i$ and its neighbor $j$ (Bonacich, 1972). It is important to stress that the estimation of eigenvector centrality requires information on the structure of linkages in the whole sub-network. Eigenvector centrality is a measure of the influence of a node in the network based on the concept that connections to high-scoring nodes contribute more to the score of the focal node than equal connections to lowscoring nodes. Therefore, in our network it reflects the degree to which a cluster is connected to other highly connected clusters. 
Once the horizontal and vertical eigenvector centralities are calculated for each cluster, we will use multivariate analysis of variance (MANOVA) to test if there are statistically significant group differences in cluster means. A confirmation of the test will allow us to categorize the clusters into the four groups discussed in the theory section.

\section{Estimation Model}

We will next use regression analysis to investigate how dynamics in a cluster's multiplex embeddedness is related to its local innovation performance. Specifically, we will conduct a longitudinal negative binomial regression with fixed effects where the "number of patents" for location $i$ in industry $k$ and period $t, P_{i k t}$, acts as the dependent variable:

$P_{i k t}=\alpha+f e_{i}+f e_{k}+f e_{t}+\beta_{1} H C_{\mathrm{ikt}}+\beta_{2} H C_{\mathrm{ikt}} * T_{i k t}+\gamma_{1} V C_{\mathrm{ikt}}+\gamma_{2} V C_{\mathrm{ikt}} * T_{i k t}+$ $\mathbf{L}_{\mathrm{ikt}} \delta+u_{i k t}$,

where $f e_{i}, f e_{k}$ and $f e_{t}$ are industry, location and period dummies; $H C_{\mathrm{ikt}}$ and $V C_{\mathrm{ikt}}$ are a location i's eigenvector centrality in the horizontal partnership and vertical buyer-supplier sub-networks in industry $k$ and period $t ; T_{\mathrm{ikt}}$ is a dummy variable that takes on the value of 1 if the cluster is knowledge-intensive and 0 otherwise; $\mathbf{L}_{\mathrm{ikt}}$ is a vector of cluster-specific control variables; and $u_{i k t}$ is a stochastic error term. Hypothesis 1 will hold if $\beta_{1}$ is positive, $\beta_{2}$ is negative and $\beta_{1}>\left|\beta_{2}\right|$. Hypothesis 2 will be confirmed if both $\gamma_{1}$ and $\gamma_{2}$ are positive.

\section{Dependent variable: number of patents}

We have gone to considerable lengths to obtain cluster-specific patent data.

United States. U.S. cluster patent data were obtained from the US Cluster Mapping Project, which collected them from the U.S. Patent and Trademark Office (USPTO). Patents by location of inventor are allocated to industries and clusters using a concordance of technology classifications with these codes to clusters. 
Canada. Canadian patent data come from the USPTO (patents are aggregated by industry and location of inventor).

Mexico. Mexican patent data come from SIGA. Mexico has undertaken a data alignment and cluster definition matching exercise to ensuring compatibility with the U.S. mapping project.

Europe. The EU cluster observatory gives patent data at the regional level, but not by industry. Therefore, we have instead used the EPO database and have identified patents by industry and location of investor. We used the Cooperative Patent Classification (CPC) system that has been jointly developed by the EPO and the USPTO to ensure proper industry concordance.

Finally, since our network data have been collected in periods of multiple years, we have calculated the average number of patents for a cluster during each period.

\section{Key variables of interest: network centrality}

Our key independent variables of interest are a cluster i's eigenvector centrality in the horizontal partnership sub-network $H C_{\mathrm{ikt}}$ and in the vertical buyer-supplier sub-network $V C_{\mathrm{ikt}}$, as well as their interactions with the dummy variable $T_{\mathrm{ikt}}$.

\section{Control variables}

We include a set of cluster-specific controls identified by prior literature. First, we add a cluster's eigenvector centrality in the intra-firm sub-network as a control variable. As we have discussed above, cluster firms not only develop inter-organizational connections with partners in other clusters, but also set up intra-firm linkages. Since it is difficult to identify whether an intra-firm linkage between two subsidiaries of the same firms is horizontal or vertical of nature, we have only focused on inter-organizational linkages to test our hypotheses.

Second, we include variables that capture the number of formal linkages between firms within the same cluster: number of local buyer-supplier linkages, number of local intra-firm linkages, and 
number of local partnership linkages. To capture the connectedness among firms within a cluster, we use cluster density which divides the number of existing local linkages by all possible linkages.

Third, we use data from the European Cluster Observatory, U.S. Cluster Mapping Project, Canadian Cluster Database and Mexico's INADEM/INEGI to add several measures that capture a cluster's economic profile and specialization. Drawing on prior work (Delgado et al., 2014), we include employment-based $L Q$ as a regressor which measures the share of a location's employment in an industry as compared to the share of North America and Greater Europe's total employment in that industry. ${ }^{11}$ We also include a cluster's average wage and the amount of R\&D investments. All measures are expected to have a positive relation with a cluster's innovation performance.

Fourth, we include a control for human capital. Since cluster observatories do not give a comparable measure of human capital, we took data on the percent of labor force with tertiary education from OECD regional statistics. Since OECD does not give U.S. regional data, we complemented this with U.S. NSF statistics on the educational level of the labor force.

Finally, we include industry and location dummies to control for other non-time-varying differences across locations and industries that are related to a cluster's innovation performance. To control for period-specific shocks that are common across locations and industries, we include period dummies. It is important to point that the inclusion of location dummies means that any nontime-varying differences between locations are controlled for. Consistent with our hypothesis, this implies that our estimates should be interpreted as changes over time: a positive coefficient on $\ln ($ centrality) means that a cluster with a disproportionately high growth in centrality has a larger increase in number of patents.

\footnotetext{
${ }^{11}$ Our sample demonstrated significant variability in LQ, ranging from 0.8 to 6.17 .
} 


\section{RESULTS}

\section{Cluster archetypes}

Figure 2 presents scatter plots with on the $x$ and $y$-axes a cluster's eigenvector centrality in the vertical buyer-supplier and horizontal partnership sub-networks respectively for the period 20102014. In the left panel, we solely use the network of international linkages to calculate the horizontal and vertical eigenvector centralities. A downside of solely using international linkages, however, is that it does capture the indirect channels through which a cluster may tap into foreign pockets of knowledge. In a network setting, a focal cluster may tap into foreign knowledge and capabilities through intra-national connections to partner clusters that themselves are internationally connected (indirect international ties). In the right panel, we thus consider the network of trans-local (regional and international) linkages to calculate a cluster's eigenvector centrality in the horizontal and vertical sub-network.

\section{[Figure 2 about here]}

A quick eyeballing of both panels suggests that there is a natural categorization in the data: most clusters are agglomerated in one of the four quadrants. In addition, most clusters fit the descriptions that we offered before. The Seattle cluster (aerospace), Boston/Massachusetts cluster (biopharma) and Silicon Valley cluster (ICT), for example, are identified as globally embedded cluster that are central in both the horizontal and vertical sub-networks. The Raleigh cluster (biopharma) and TechnoMontreal (ICT) are horizontally embedded cluster with a high horizontal centrality and a low vertical centrality. Queretaro (aerospace) and Central Poland cluster (ICT) which specializes in supplying parts and components for global value chains are categorized as a vertically embedded cluster with high vertical centrality and low horizontal centrality. Finally, the Siberian aerospace cluster in Russia and Lviv ICT cluster in Ukraïne are examples of peripheral clusters which have a strong local innovation and supplier system, but which are not well integrated in the horizontal and vertical sub-networks. 
Multivariate analysis of variance (MANOVA) supports our categorization empirically. The analysis tests difference in means between the 4 groups of clusters on 2 dimensions: vertical and horizontal eigenvector centrality. The results indicate that our categorization of clusters in the three industries is significant at the $2 \%$ level when considering the network of international linkages, and at the $5 \%$ level when considering the network of trans-local linkages. Moreover, the results indicate that there is a significant stratification in the networks and that there is a clear core-periphery network community structure.

\section{Benchmark results}

To test our hypotheses, we have categorized clusters into two groups: labor-intensive clusters (peripheral in the horizontal sub-network) and knowledge-intensive clusters (central in the horizontal sub-network). ${ }^{12}$ Next we created a dummy variable $T$ that takes the value of 1 for the former group and zero for the latter.

Descriptive statistics for our dependent and independent variables are presented in Table 3 . The correlation coefficients between the various measures of eigenvector centrality are small, suggesting that our analysis is not subject to multicollinearity.

\section{[Table 3 about here]}

A common way to estimate a regression that uses a count measure as a dependent variable is a Poisson regression. The Poisson model, however, requires that the variance of the dependent variable equals its mean, which is often violated thus leading to an over-dispersion problem. We tested for potential over-dispersion in two ways. First, we divided the Pearson chi-square and deviance values by the degrees of freedom. This procedure gave us values of 2.87 and 3.35, which are both above the threshold of one, suggesting over-dispersion. Second, we performed a likelihood

\footnotetext{
${ }^{12}$ We use 0.35 value as a cut-off between labor-intensive and knowledge-intensive clusters.
} 
ratio test by calculating the double difference between the log likelihood values of the Poisson and the equivalent negative binomial estimation. This test resulted in a chi-square statistic of 807.64 $(\mathrm{p}<0.001)$, suggesting there is over-dispersion. The negative binomial model provides a useful generalization that does not rely on the mean-variance equality restriction and we proceeded with estimating the models using negative binomial regressions.

We also tested for spatial autocorrelation using Moran's I statistic. We first generated a matrix of inverse distance weights. In the matrix, entries for pairs of points that are close together are higher than for pairs of points that are far apart. We used cluster geographic GPS coordinates to calculate distance. Then we generated a distance matrix, took the inverse of the matrix values and replaced the diagonal entries with zero. Finally, we performed Moran's I test, which at a p-value of 0.017 suggested evidence of spatial autocorrelation. Since we use negative binomial model, we cannot use exogenous spatial lags. A typical solution in such a situation is modelling the autocorrelation in the errors of the system. We modelled the error in all our models by including eigenvector terms based on the weighted residuals (Dormann et al., 2007).

Table 4 reports the results of our benchmark regression analysis. Column 1 of Table 4 provides the results with only the cluster-specific control variables, the location, industry and period dummies. Column 2 adds to the regressors our main variables of interest: horizontal eigenvector centrality, vertical eigenvector centrality and their interaction terms with dummy $T$. Column 3 re-runs the results when the network of trans-local linkages are used to calculate the centrality measures. Column 4 re-runs the analysis when only regional linkages are used to calculate the centrality measures.

\section{[Table 4 about here]}

The results in table 4 provide empirical support for our hypotheses 1 and 2 . In column 2, the positive and significant coefficient on both $\operatorname{In}$ (vertical eigen. centrality) and the interaction term $\ln$ (vertical 
eigen. centrality) $* T$ suggest that a $1 \%$ increase in a cluster's centrality in the vertical buyer-supplier sub-network leads to a larger improvement in innovation performance for labor-intensive clusters than for knowledge-intensive clusters. The positive coefficient on $\ln ($ horizontal eigen. centrality) and the smaller negative coefficient on the interaction term $\ln ($ horizontal eigen. centrality)*T suggests that a $1 \%$ rise in centrality in the horizontal partnership sub-network leads to a larger improvement in innovation performance for knowledge-intensive clusters than for labor-intensive clusters.

The results in column 3 of table 4 suggest that these results continue to hold when we consider the network of trans-local linkages (regional + international). Indeed, the coefficients on our four key independent variables take on the same signs as in column 2 and remain significant. However, the smaller coefficients in column 3 compared to column 2 indicate that innovation performance in both types of clusters is less sensitive to centrality improvements in the trans-local sub-networks (regional and international linkages) than in the international sub-networks. This suggests that it is particularly centrality improvements in the network of international linkages that positively affects a cluster's innovation performance.

The results in column 4 of table 4 provide further evidence that centrality improvements in the international network matter more than in the intra-national network. When only the network of regional linkages is considered, the coefficients on $\ln$ (vertical eigen. centrality) and $\ln ($ vertical eigen. centrality) $* T$ become insignificant, while the absolute values of the coefficients on $\ln$ (horizontal eigen. centrality) and $\ln$ (horizontal eigen. centrality)*T are smaller and have a lower significance than in columns 2 and 3.

Our control variables take on the expected signs. The positive sign on intra-firm eigenvector centrality suggests that a cluster's centrality in the intra-firm sub-network is positively related with its local innovation performance. The positive coefficients on $L Q, R \& D$ investment, labor force 
education and cluster density indicate that clusters with a stronger than average growth in their industrial concentration, $R \& D$ investment, human capital and cluster density have an above average increase in patents. Local partnership and intra-firm linkages also are positively related to a cluster's innovation performance. In contrast, the coefficients on local buyer-supplier linkages and wages are insignificant.

\section{Developed-country versus emerging-market clusters}

A criticism that one could raise about our analysis is that we use network information to distinguish between knowledge-intensive (horizontally central) and labor-intensive (horizontally peripheral) clusters. As a robustness test, we in this section use the distinction between emerging-market versus developed-country clusters as an alternative proxy for labor-intensive and knowledge-intensive clusters, respectively. In other words, we created a dummy variable that takes on a value of 1 if a cluster is located in an emerging country and 0 otherwise.

The results in columns 5-7 of table 4 suggest that it does not alter our key results. None of the coefficients on our key independent variables switch sign or significance and the sizes of all coefficients are similar to before. Our results thus continue to provide empirical support for our hypotheses. We also continue to find that a cluster's innovation performance is more sensitive to centrality improvements in the international sub-networks than in the regional sub-networks.

\section{Reverse Causality}

Another issue with our analysis in table 4 is that we cannot make any inference about causation. Clusters that improve their innovation performance may attract more and better linkages. To address this possibility of reverse causality between centrality and innovation (i.e. innovation $\rightarrow$ centrality), we in the appendix used a random effects panel approach to study the impact of number of patents and the interaction of number of patents* $T$ on horizontal and vertical eigenvector centrality, after including all our cluster-specific control variables. The random effects model 
estimates variation between and within subjects and gives 3 types of R-squared: within, between and overall. It captures how the model subjects change over time and treats observations for the same cluster in different time-periods as interdependent. We conducted these tests separately for the international, trans-local and regional sub-networks. In 11 of the 12 regressions, the coefficients on number of patents and the interaction term number of patents $* T$ were insignificant. The only exception is regression (4) where we found weak evidence (at the $10 \%$ level) that an increase in number of patents significantly improves a cluster's horizontal eigenvector centrality when only international linkages are considered. Overall, these experiments suggest that, most likely, the relationship runs in the direction centrality $\rightarrow$ innovation.

\section{Lagged regressors}

As a final robustness test, we in table 5 estimated our regression using lagged independent variables from period $t-1$. The use of lags is appropriate since it is reasonable to expect a time lag between a cluster's efforts to change its embeddedness in the global cluster network and its effects on local innovation performance in the subsequent period. The reduction in the number of observation from 446 to 290 , however, requires us to drop the location and period dummies to ensure sufficient degrees of freedom.

Columns 1-3 in table 5 focus on the distinction between labor-intensive versus knowledge-intensive clusters, while columns 4-6 focus on the distinction between emerging-market versus developedcountry clusters. The results show that, even though model fit is worse in the models where we use lagged regressors, the coefficients for our independent variables show similar patterns as in table 4. Furthermore, we continue to find consistent evidence that a cluster's innovation performance is more sensitive to centrality improvements in the international sub-networks than in the regional sub-networks.

\section{[Table 5 about here]}




\section{DISCUSSION AND CONCLUDING REMARKS}

The global dispersion of value creation in today's knowledge economy has renewed the interest in how clusters obtain the required knowledge to strengthen their local innovation performance. Now more than ever, constituent firms in a cluster are expanding their knowledge networks to tap into distant knowledge pockets, and this is affecting the knowledge base of clusters (Cantwell \& Mudambi, 2005). Established knowledge hotspots like Silicon Valley (ICT), Montréal (Aerospace) and San Diego (Biotech) rely on the global connectedness of their firms to foreign locations to constantly reinforce their local innovation capabilities. Emergent clusters such as Queretaro (aerospace) and Tallinn (ICT) increasingly integrate into global knowledge networks by becoming suppliers for global value chains. The question thus emerges as to which type of organization-based connections should be constructed by constituent MNEs to strengthen the link between global connectedness and local innovation performance, and whether this interaction depends on a cluster's relative position in global knowledge networks. In other words, our study offers both an analytical as well as a predictive framework for the pattern of MNE knowledge sourcing within the relevant global innovation network.

In this paper, we have developed a theory of the "global cluster network" that provides new and more nuanced insights into these issues. In our framework, clusters are treated as network nodes that are connected to foreign clusters through two different types of organization-based linkages: (1) horizontal ties between firms that specialize in similar value chain activities which provide access to lateral intra-task knowledge competencies, and (2) vertical ties between firms that specialize in different value chain activities which provide access to value chain-specific inter-task knowledge competencies. We have operationalized the model empirically by hand-collecting longitudinal data on regional and international firm linkages between North American and European clusters in three knowledge-intensive industries (aerospace, ICT and Biopharma) during the period 2002-2014. 
In the context of our framework, we have argued that the global cluster network provides valuable information about clusters' relative positions in an industry that goes beyond simple categorizations based on the development level of the country in which they are located or on their technological profile (see also Awate \& Mudambi, 2017). A cluster's multiplex position in the network reveals key information about its intra-industry specialization pattern. The central position of the Amsterdam biotech cluster and the Montréal ICT cluster in the horizontal sub-network exposes that they specialize in core knowledge-intensive tasks since it is in this type of activities that competition disproportionately prompts firms to look for distinctive lateral knowledge in distant locations (Berry, 2014; Cantwell, 1989). The central position of Aviation Valley in Poland or the PragueStredni Sechy ICT cluster in the vertical sub-network reveals that they specialize in core value chain stages since it is companies that concentrate on this type of activities that disproportionately develop buyer-supplier linkages to foreign locations specializing in complementary value chain stages (Pietrobelli \& Rabellotti, 2011). We have used these insights to categorize clusters into four archetypes based on their relative value chain position in the industry.

In addition, since the network positions of clusters evolve over time, we have used such network dynamics to evaluate how a dynamic change in a cluster's position in the global cluster network affects its local innovation capabilities. We have proposed and found empirical evidence that innovation in knowledge-intensive clusters (central in the horizontal sub-network) disproportionately benefits from dynamic improvements in horizontal centrality. In other words, for established knowledge clusters, innovation at home is primarily spurred when its constituent firms strengthen their lateral connectedness to other knowledge hotspots. The results are different for labor-intensive clusters (peripheral in the horizontal sub-network) whose innovation performance disproportionately gains from strengthening centrality in the vertical sub-network. In other terms, for clusters that are involved in more standardized value chain activities, it is the 
construction of vertical connections to more central value chain partners by its constituent firms that provides, so to speak, more bang for the innovation buck.

These findings confirm that there is no one-size-fits-all recommendation on how a cluster should optimally build its international connectedness. That is, cluster internationalization programs such as the European Cluster Collaboration Platform should not simply aim to facilitate international collaborations between constituent firms and companies in foreign clusters. Depending on a cluster's relative position in the global cluster network, they should promote a different connectivity strategy to catalyze local innovation activities. Knowledge clusters compete to attract and retain knowledge-intensive activities, and improvements in lateral connectivity to other knowledge hotspots improves their chances to do so. In labor-intensive clusters, then again, innovation catch-up depends on the ability to climb up the value chain ladder (Humphrey \& Schmitz, 2002; Mudambi, 2008; Van Assche \& Van Biesebroeck, 2017), and improved vertical connectedness to more central value chain players is a means to this end.

It is important to point out two important nuances about our results. First, labor-intensive clusters do not specifically refer to locations in developing countries (see also Mudambi and Santangelo, 2016). In our sample, developed-country clusters are typically central in the horizontal subnetwork, whereas emerging-market clusters are peripheral. However, the match is not perfect. Basque aerospace cluster and Lombardia ICT cluster are just two examples of developed-country clusters that are peripheral in the horizontal sub-network. Second, our results do not suggest that labor-intensive clusters are eternally condemned to be peripheral players in the horizontal subnetwork. As such clusters over time improve their vertical centrality and upgrade into more knowledge-intensive value chain activities, competition should start pushing constituent firms to seek distinctive lateral knowledge abroad, thus raising their horizontal centrality and allowing them 
to turn into knowledge-intensive clusters. Future research is needed to identify this dynamic transition process in greater detail.

Our analysis also contributes to the international business literature on the geography of knowledge sourcing. Recent international business studies have argued that discontinuities at the border ensure that international knowledge-based linkages are more selective and valuable than regional linkages (Beugelsdijk \& Mudambi, 2013; Scalera et al., 2018). Our paper provides evidence in favor of this claim. If regional linkages are added to our global cluster network, we find that improvements in global connectedness has a substantially smaller effect on local innovation performance than if they are not included. And if we only consider the network of regional linkages in our empirical analysis, the link between global connectedness and local innovation performance virtually disappears. More research is needed to study why this is the case.

As in any research, our paper has a number of limitations that open up avenues for future work. First, we used simple patent count to capture a cluster's innovation performance, which is known to be an imperfect proxy for innovation (Carlino \& Kerr, 2015). It has been well documented that not all patented inventions are commercially valuable, and that not all innovations are patented. Furthermore, patent count ignores the various types of innovation (e.g. process versus product innovation) and technology classes in which clusters can specialize. A particularly promising avenue of future research would be to explore how a cluster's archetype is related to its position in technological space (e.g. Awate \& Mudambi, 2017).

Second, in future work, it would be interesting to improve the granularity of our analysis by focusing on the relative position of the firm, and particularly the MNE, in the global cluster network. This would allow us to gain deeper insights into the firm-level factors that drive the formation of network ties and how they contribute to the overall structural properties of the network. Which type of firms are more central in the global cluster network? Are multinational 
firms more likely to span boundaries between network communities? Obtaining an answer to these questions are crucial for deepening our understanding how firms and clusters co-evolve and how this affects their performance and upgrading potential.

Finally, while our network dataset is more comprehensive than existing network databases on industrial clusters in the spatial, time and industry dimension, it could be expanded in a number of directions. We only capture linkages between clusters, thus ignoring organization-based the numerous ties that clusters develop with non-cluster locations (Li \& Bathelt, 2018). Our dataset could be enlarged to include some of the world's most dynamic emerging regions (East Asia and Latin America). These further improvements should broaden and deepen our understanding how clusters can bolster their innovation through international connectedness. 


\section{BIBLIOGRAPHY}

Ahuja, G. 2000. Collaboration networks, structural holes, and innovation: A longitudinal study. Administrative Science Quarterly, 45(3): 425-455.

Alcácer, J., Cantwell, J., \& Piscitello, L. 2016. Internationalization in the information age: A new era for places, firms, and international business networks? Journal of International Business Studies, 47(5): 499-512.

Alcacer, J., \& Oxley, J. 2014. Learning by supplying. Strategic Management Journal, 35(2): 204223.

Alfaro, L., \& Charlton, A. 2009. Intra-industry foreign direct investment. The American Economic Review, 99(5): 2096-2119.

Almeida, P., \& Phene, A. 2004. Subsidiaries and knowledge creation: The influence of the MNC and host country on innovation. Strategic Management Journal, 25(8-9): 847-864.

Andersson, U., \& Forsgren, M. 2000. In search of centre of excellence: Network embeddedness and subsidiary roles in multinational corporations. Management International Review, 329-350. Arora, A., Fosfuri, A. \& Gambardella, A. 2001. Markets for technology: The economics of innovation and corporate strategy. Boston: MIT Press.

Asakawa, K., Park, Y., Song, J., \& Kim, S. 2018. Internal embeddedness, geographic distance, and global knowledge sourcing by overseas subsidiaries. Journal of International Business Studies, forthcoming.

Awate, S., \& Mudambi, R. (2017). On the geography of emerging industry technological networks: the breadth and depth of patented innovations. Journal of Economic Geography, 18(2): 391-419.

Bathelt, H., Malmberg, A., \& Maskell, P. 2004. Clusters and knowledge: local buzz, global pipelines and the process of knowledge creation. Progress in Human geography 28(1): 31-56. 
Beugelsdijk, S., \& Mudambi, R. 2013. MNEs as border-crossing multi-location enterprises: The role of discontinuities in geographic space. Journal of International Business Studies, 44(5): 413426.

Berry, H. 2014. Global integration and innovation: Multicountry knowledge generation within MNCs. Strategic Management Journal, 35(6): 869-890.

Bonacich, P. 1972. Factoring and weighting approaches to clique identification. Journal of Mathematical Sociology, 2: 113-120.

Boschma, R. 2005. Proximity and innovation: a critical assessment. Regional studies, 39(1): 6174.

Boschma, R. \& Ter Wal, A. 2007. Knowledge networks and innovative performance in an industrial district: the case of a footwear district in the South of Italy. Industry and Innovation, 14(2): 177-199.

Buciuni, G., \& Pisano, G. 2015. Can Marshall's Clusters Survive Globalization? Harvard Business School. Mimeo.

Burt, R. 1992. Structural hole. Harvard Business School Press, Cambridge, MA.

Cano-Kollmann, M., Cantwell, J., Hannigan, T. J., Mudambi, R., \& Song, J. 2016. Knowledge connectivity: An agenda for innovation research in international business. Journal of International Business Studies, 47(3), 255-262.

Cantwell, J. 1989. Technological Innovation and Multinational Corporations. Oxford: Basil Blackwell.

Cantwell, J. 2009. Location and the multinational enterprise. Journal of International Business Studies, 40(1): 35-41.

Cantwell, J., Dunning, J., \& Lundan, S. 2010. An evolutionary approach to understanding international business activity: The co-evolution of MNEs and the institutional environment. Journal of International Business Studies, 41(4), 567-586. 
Cantwell, J., \& Janne, O. 1999. Technological globalisation and innovative centres: the role of corporate technological leadership and locational hierarchy. Research policy, 28(2): 119-144.

Cantwell, J., \& Mudambi, R. 2005. MNE competence-creating subsidiary mandates. Strategic Management Journal, 26(12): 1109-1128.

Cantwell, J. A., \& Mudambi, R. 2011. Physical attraction and the geography of knowledge sourcing in multinational enterprises. Global Strategy Journal, 1(3-4), 206-232.

Cantwell, J., \& Santangelo, G. 1999. The frontier of international technology networks: sourcing abroad the most highly tacit capabilities. Information Economics and Policy, 11(1): 101-123.

Carlino, G., \& Kerr, W. 2015. Agglomeration and Innovation. Handbook of Regional and Urban Economics, 349.

Chung, W., \& Yeaple, S. 2008. International knowledge sourcing: Evidence from US firms expanding abroad. Strategic Management Journal, 29(11): 1207-1224.

Coleman, J. (1988). Social capital in the creation of human capital. American Journal of Sociology, S95-S120.

Crespo, N., \& Fontoura, M. 2007. Determinant Factors of FDI Spillovers-What Do We Really Know? World development, 35(3): 410-425.

Delgado, M., Porter, M. \& Stern, S. 2010. Clusters and entrepreneurship. Journal of Economic Geography 10(4): 495-518.

Delgado, M., Porter, M., \& Stern, S. 2014. Clusters, convergence, and economic performance. Research Policy 43(10): 1785-1799.

De Marchi, V., \& Grandinetti, R. (2014). Industrial districts and the collapse of the Marshallian model: looking at the Italian experience. Competition \& Change, 18(1), 70-87.

Dhanaraj, C., \& Parkhe, A. 2006. Orchestrating innovation networks. Academy of management review, 31(3): 659-669. 
Dormann, C., McPherson, M., Araújo, M., Bivand, R., Bolliger, J., Carl, G. \& Kühn, I. 2007. Methods to account for spatial autocorrelation in the analysis of species distributional data: a review. Ecography, 30(5) : 609-628.

Dussauge, P., \& Garrette, B. 1995. Determinants of success in international strategic alliances: Evidence from the global aerospace industry. Journal of International Business Studies, 26(3): 505530.

Dyer, J., \& Singh, H. 1998. The relational view: Cooperative strategy and sources of interorganizational competitive advantage. Academy of Management Review, 23(4) : 660-679.

Farrell, D. 2005. Offshoring: Value creation through economic change. Journal of Management Studies, 42(3): 675-683.

Florida, R. 2002. The Rise of the Creative Class. New York: Basic Books.

Freeman, L. 1979. Centrality in networks: I. Conceptual clarification. Social Networks 1, 215-239.

Gereffi, G., Humphrey, J., \& Sturgeon, T. 2005. The governance of global value chains. Review of International Political Economy, 12(1): 78-104.

Galunic, D., \& Rodan, S. (1998). Resource recombinations in the firm: Knowledge structures and the potential for Schumpeterian innovation. Strategic management journal, 1193-1201.

Ghoshal, S., Korine, H., \& Szulanski, G. 1994. Interunit communication in multinational corporations. Management Science, 40(1): 96-110.

Giroud, A., \& Scott-Kennel, J. 2009. MNE linkages in international business: A framework for analysis. International Business Review, 18(6), 555-566.

Giuliani, E. 2007. The selective nature of knowledge networks in clusters: evidence from the wine industry. Journal of Economic Geography, 7(2): 139-168.

Giuliani, E., \& Bell, M. 2005. The micro-determinants of meso-level learning and innovation: evidence from a Chilean wine cluster. Research policy, 34(1): 47-68. 
Giuliani, E., Pietrobelli, C., \& Rabellotti, R. 2005. Upgrading in global value chains: lessons from Latin American clusters. World Development, 33(4): 549-573.

Granovetter, M. 1985. Economic action and social structure: The problem of embeddedness. American Journal of Sociology, 91(3) : 481-510.

Gulati, R. 1999. Network location and learning: The influence of network resources and firm capabilities on alliance formation. Strategic Management Journal, 20(5): 397-420.

Gulati, R. 2007. Managing network resources: Alliances, affiliations, and other relational assets. Oxford University Press.

Gulati, R., \& Westphal, J. 1999. Cooperative or controlling? The effects of CEO-board relations and the content of interlocks on the formation of joint ventures. Administrative Science Quarterly, 44(3): 473-506.

Hannigan, T., Cano-Kollmann, M., \& Mudambi, R. 2015. Thriving innovation amidst manufacturing decline: the Detroit auto cluster and the resilience of local knowledge production. Industrial and Corporate Change, 24(3): 613-634.

Humphrey, J., \& Schmitz, H. 2002. How does insertion in global value chains affect upgrading in industrial clusters? Regional studies, 36(9), 1017-1027.

Inkpen, A. 1998. Learning and knowledge acquisition through international strategic alliances. The Academy of Management Executive, 12(4): 69-80.

Iurkov, V. \& Benito, G. 2017. Domestic alliance networks and regional strategies of MNEs: A structural embeddedness perspective. Journal of International Business Studies, forthcoming.

Jaffe, A., Trajtenberg M. \& Henderson, R. 1993. Geographic localization of knowledge spillovers as evidenced by patent citations. Quarterly Journal of Economics, 108(3): 577-598.

Javorcik, B. 2008. Can Survey Evidence Shed Light on Spillovers from Foreign Direct Investment? The World Bank Research Observer, 23(2): 139-159. 
Kano, L. 2018. Global value chain governance: a relational perspective. Journal of International Business Studies, forthcoming.

Lavie, D. 2006. The competitive advantage of interconnected firms: An extension of the resourcebased view. Academy of Management Review, 31(3), 638-658.

Lorenzen, M. \& Mudambi, R. 2013. Clusters, connectivity and catch-up: Bollywood and Bangalore in the global economy. Journal of Economic Geography 13(3): 501-534.

Li, P. \& Bathelt, H. 2018. Location strategy in cluster networks. Journal of International Business Studies, forthcoming.

Mahmood, I. P., Zhu, H., \& Zajac, E. J. 2011. Where can capabilities come from? Network ties and capability acquisition in business groups. Strategic Management Journal, 32(8), 820-848.

Malmberg, A., \& Maskell, P. 2006. Localized learning revisited. Growth and Change, 37(1), 1-18. Maskell, P., \& Malmberg, A. 1999. Localised learning and industrial competitiveness. Cambridge Journal of Economics, 23(2): 167-185.

McEvily, B., \& Marcus, A. 2005. Embedded ties and the acquisition of competitive capabilities. Strategic management journal, 26(11), 1033-1055.

Mesquita, L., \& Lazzarini, S. 2008. Horizontal and vertical relationships in developing economies: Implications for SMEs' access to global markets. Academy of Management Journal 51(2): 359-380. Meyer, K., Mudambi, R., \& Narula, R. 2011. Multinational enterprises and local contexts: The opportunities and challenges of multiple embeddedness. Journal of Management Studies, 48(2): $235-252$.

Mudambi, R. 2008. Location, control and innovation in knowledge-intensive industries. Journal of Economic Geography, 8(5): 699-725.

Mudambi, R., \& Santangelo, G. 2016. From shallow resource pools to emerging clusters: the role of multinational enterprise subsidiaries in peripheral areas. Regional Studies 50(12): 1965-1979. 
Niosi, J., Zhegu, M. 2005. Aerospace clusters: local or global knowledge spillovers? Industry \& Innovation, 12(1): 5-29.

Owen-Smith, J., \& Powell, W. 2004. Knowledge networks as channels and conduits: The effects of spillovers in the Boston biotechnology community. Organization science, 15(1): 5-21.

Pietrobelli, C., \& Rabellotti, R. 2011. Global value chains meet innovation systems: are there learning opportunities for developing countries? World Development, 39(7): 1261-1269.

Pisano, G., \& Shih, W. 2009. Restoring American competitiveness. Harvard business review, 87(7/8): 114-125.

Podolny, J. 2001. Networks as the Pipes and Prisms of the Market. American Journal of Sociology, 107(1): 33-60.

Porter, M. 1998. On competition. Boston: Harvard Business School Press.

Powell, W., Koput, K., \& Smith-Doerr, L. 1996. Interorganizational collaboration and the locus of innovation: Networks of learning in biotechnology. Administrative Science Quarterly, 116-145. Roijakkers, N., \& Hagedoorn, J. 2006. Inter-firm R\&D partnering in pharmaceutical biotechnology since 1975: Trends, patterns, and networks. Research policy, 35(3): 431-446.

Rugman, A., \& Verbeke, A. 2003. Multinational enterprises and clusters: An organizing framework. Management International Review, 43, 151-169.

Scalera, V., Perri, A., \& Hannigan, T. J. 2018. Knowledge connectedness within and across home country borders: Spatial heterogeneity and the technological scope of firm innovations. Journal of International Business Studies, forthcoming.

Shipilov, A. 2012. Strategic multiplexity. Strategic Organization, 10(3): 215-222.

Singh, J. 2005. Collaborative networks as determinants of knowledge diffusion patterns. Management Science 51(5): 756-770.

Soh, P., Mahmood, I., \& Mitchell, W. 2004. Dynamic inducements in R\&D investment: Market signals and network locations. Academy of Management Journal, 47(6) : 907-917. 
Storper, M., \& Venables, A. J. 2004. Buzz: face-to-face contact and the urban economy. Journal of economic geography, 4(4): 351-370.

Stuart, T., Hoang, H., \& Hybels, R. 1999. Interorganizational endorsements and the performance of entrepreneurial ventures. Administrative science quarterly, 44(2): 315-349.

Sturgeon, T. 2003. What really goes on in Silicon Valley? Spatial clustering and dispersal in modular production networks. Journal of Economic Geography, 3(2): 199-225.

Sturgeon, T., Van Biesebroeck, J., \& Gereffi, G. 2008. Value chains, networks and clusters: reframing the global automotive industry. Journal of Economic Geography, 8(3): 297-321.

Turkina, E., Van Assche, A., \& Kali, R. 2016. Structure and evolution of global cluster networks: evidence from the aerospace industry. Journal of Economic Geography, 16(6): 1211-1234.

Van Assche, A. 2017. Global value chains and innovation. Chapter 45 in H. Bathelt., P. Cohendet, S. Henn and L. Simon (eds.). The Elgar Companion to Innovation and Knowledge Creation: A Multi-disciplinary Approach, Edward Elgar.

Van Assche, A., \& Van Biesebroeck, J. 2018. Functional upgrading in China's export processing sector. China Economic Review 47(1): 245-262.

Wasserman, S., \& Faust, K. 1994. Social network analysis: Methods and applications (Vol. 8). Cambridge University Press.

Wolfe, D., \& Gertler, M. 2004. Clusters from the inside and out: local dynamics and global linkages. Urban Studies, 41(5-6): 1071-1093.

Zaheer, A., Gözübüyük, R., \& Milanov, H. 2010. It's the connections: The network perspective in interorganizational research. The Academy of Management Perspectives, 24(1): 62-77. 
Table 1: List of clusters, by industry and location

\begin{tabular}{|c|c|c|}
\hline & Developed Country Clusters & Emerging Market Clusters \\
\hline Aerospace & $\begin{array}{l}\text { US: Baltimore-Salisbury, Boston area, } \\
\text { Central/Eastern Washington, Dallas-Fort Worth- } \\
\text { Kileen, Georgia, Hartford-Bridgeport, Little Rock } \\
\text { area, Maine Aerospace Alliance (MEAA), } \\
\text { Manchester-Concord, Metro Denver and Northern } \\
\text { Colorado, North Alabama, Northwest Florida, } \\
\text { Ogden-Salt Lake City, Southern Arizona, Southern } \\
\text { California, Southwest Ohio, Vermont Aerospace \& } \\
\text { Aviation (VAAA), Washington DC-West Virginia, } \\
\text { Wichita. } \\
\text { Canada: Aeromontréal, Greater Vancouver, Nova } \\
\text { Scotia, Southern Ontario. } \\
\text { Europe: Aerospace Valley, Andalusia, ASTech Paris } \\
\text { cluster, BavAIRia, Berlin-Brandenburg Aerospace } \\
\text { Alliance (BBAA), Belfast cluster, Campaniaerospace, } \\
\text { Hamburg cluster, HEGAN Basque, Lombardia, } \\
\text { Madrid, Northwest aerospace alliance (NWAA), Pole- } \\
\text { Pegase, Rhone-Alps, Skywin, Swiss, FLAG cluster. }\end{array}$ & $\begin{array}{l}\text { Queretaro, Chihuahua, Sonora } \\
\text { Northwestern, Jalisco, Baja } \\
\text { California, Estado de Mexico, } \\
\text { Aviation Valley, HAG cluster, Izmir } \\
\text { cluster, Moravian aerospace cluster, } \\
\text { Transylvania aerospace cluster, } \\
\text { Siberian cluster }\end{array}$ \\
\hline Biopharma & $\begin{array}{l}\text { US: Boston/Massachussetts, Chicago, Florida, Grand } \\
\text { Rapids, Los Angeles, Maryland Minneapolis/St. Paul, } \\
\text { New York, Philadelphia, Raleigh, Rochester, Saint } \\
\text { Louis, San Diego, San Fransisco, San Jose, Seattle, } \\
\text { Texas. } \\
\text { Canada: Manitoba, Montréal, Oshawa, Toronto, } \\
\text { Prince Edward Island } \\
\text { Europe: Alps, Amsterdam, Berlin, Biocat, BioM, } \\
\text { Bioval, Biovalley, Biowin, Cambridge, Copenhagen, } \\
\text { Food Valley, Frankfurt, Genopole, Ghent, Hamburg, } \\
\text { IAR Lebensmittel Lombardy, London, Lyon, Madrid, } \\
\text { Manchester, Medicon Valley, Munich, Oslo } \\
\text { Technopole, Oxford, Umea }\end{array}$ & $\begin{array}{l}\text { Jalisco, Northern Biocluster, } \\
\text { Pomeranian Bio-Eco-Chemical, } \\
\text { Budapest region, Szeged cluster, } \\
\text { Debrecen, Pécs cluster, Warsaw } \\
\text { region, Wroclaw and Krakow } \\
\text { clusters, Tkirdag-Istanbul cluster, } \\
\text { Balikesir cluster }\end{array}$ \\
\hline $\begin{array}{c}\text { IT/ } \\
\text { Telecom }\end{array}$ & $\begin{array}{l}\text { US: Austin, Charleston, Colorado Springs, Denver, } \\
\text { Lincoln, Madison, Minneapolis, Milwaukee, New } \\
\text { York, Orlando, Portland, Rochester, San Diego, San } \\
\text { Francisco, Seattle, Silicon Valley, Syracuse, Tucson. } \\
\text { Canada: Kitchener, Montréal, Ontario, Ottawa, } \\
\text { Vancouver } \\
\text { Europe: BBO South-East (London), Berlin, Etelä- } \\
\text { Suomi, Hovestaden, Ile de France, Lombardia, } \\
\text { Madrid, Oberbayern, Oslo, Paris Region, Software- } \\
\text { Cluster (Germany), Stockholm IT, Utrecht, Wien IT }\end{array}$ & $\begin{array}{l}\text { Baja California, Estado de Mexico, } \\
\text { Guadalajara electronics cluster, } \\
\text { Zapadne-Slovensko, Kosice IT Valley, } \\
\text { Severovychod, Stredni Morava, } \\
\text { Jihozapad, Közép-Magyarország, } \\
\text { Kozep-Dunantul, Del-Dunantul, } \\
\text { Eszak-Alfold, Pomeranian, Central } \\
\text { Poland, Dolnoslaskie cluster, } \\
\text { Lubuskie cluster, Prague-Stredni } \\
\text { Sechy, Tallin cluster, Riga, Russian } \\
\text { Northwestern IT, Vest Romanian, } \\
\text { Nord-Vest Romanian,Vilnius, Lviv IT } \\
\text { cluster, Ankara }\end{array}$ \\
\hline
\end{tabular}


Table 2: Trends in international linkages, by linkage type

\begin{tabular}{|c|c|c|c|c|c|c|}
\hline & \multicolumn{3}{|c|}{$\begin{array}{c}\text { Share of international linkages in total } \\
\text { linkages }(\%)\end{array}$} & \multicolumn{3}{|c|}{$\begin{array}{l}\text { Growth in number of linkages }(\%) \text {, } \\
2002-05 \text { to } 2010-14\end{array}$} \\
\hline & $2002-2005$ & 2006-2009 & 2010-2014 & Local & Trans-local & International \\
\hline \multicolumn{7}{|l|}{ Aerospace } \\
\hline Partnership & 5.02 & 4.89 & 4.73 & 11.60 & 8.60 & 5.18 \\
\hline Buyer-supplier & 5.63 & 6.99 & 7.18 & -12.10 & 15.30 & 13.72 \\
\hline Intra-firm & 62.11 & 64.09 & 66.12 & -13.70 & 14.20 & 20.11 \\
\hline \multicolumn{7}{|l|}{ Biopharma } \\
\hline Partnership & 7.07 & 6.98 & 6.70 & 11.20 & 6.20 & 5.25 \\
\hline Buyer-supplier & 7.93 & 8.63 & 9.02 & -8.50 & 9.60 & 6.34 \\
\hline Intra-firm & 37.60 & 38.26 & 39.18 & -5.60 & 10.70 & 13.28 \\
\hline \multicolumn{7}{|l|}{ ICT } \\
\hline Partnership & 8.86 & 8.63 & 8.31 & 14.70 & 10.20 & 7.03 \\
\hline Buyer-supplier & 26.52 & 33.47 & 39.45 & -15.90 & 17.10 & 24.16 \\
\hline Intra-firm & 77.25 & 79.02 & 80.77 & -8.20 & 15.40 & 26.01 \\
\hline
\end{tabular}

Source: Authors' calculations 
Table 3: Descriptive statistics and Pearson correlations ${ }^{a}$

\begin{tabular}{|c|c|c|c|c|c|c|c|c|c|c|c|c|}
\hline Variables & 1 & 2 & 3 & 4 & 5 & 6 & 7 & 8 & 9 & 10 & 11 & 12 \\
\hline \multicolumn{13}{|l|}{ 1. Innovation } \\
\hline 2. Eigen. centrality vertical & $0.28 * * *$ & & & & & & & & & & & \\
\hline 3. Eigen. centrality horizontal & $0.50 * * *$ & 0.05 & & & & & & & & & & \\
\hline 4. Eigen.centrality intra-firm & $0.39 * * *$ & $0.22 * *$ & $0.27 * *$ & & & & & & & & & \\
\hline 5. Loc. buyer-suppl. links & $0.15^{*}$ & 0.02 & -0.01 & 0.02 & & & & & & & & \\
\hline 6. Loc. intra-firm links & $0.25 * * *$ & -0.03 & 0.02 & 0.04 & 0.03 & & & & & & & \\
\hline 7. Loc. partnership links & $0.42 * * *$ & 0.01 & -0.12 & -0.02 & -0.14 & 0.03 & & & & & & \\
\hline 8. Cluster density & $0.36^{* * *}$ & -0.04 & -0.01 & -0.03 & $0.23 * *$ & 0.11 & $0.16^{*}$ & & & & & \\
\hline 9. Wages & $0.19^{*}$ & 0.08 & $0.17^{*}$ & 0.10 & 0.07 & 0.13 & $0.22 * *$ & 0.08 & & & & \\
\hline 10. Location quotient & $0.48 * * *$ & 0.04 & $0.18^{*}$ & 0.13 & $-0.22 * *$ & 0.12 & $0.29 * *$ & 0.09 & 0.04 & & & \\
\hline 11. $R \& D$ investments & $0.59 * * *$ & 0.09 & $0.23 * *$ & 0.14 & 0.03 & 0.11 & -0.03 & 0.13 & $0.27 * *$ & 0.08 & & \\
\hline 12. Labor force education & $0.54 * * *$ & 0.13 & $0.21 * *$ & 0.03 & 0.09 & 0.10 & $0.18^{*}$ & 0.14 & $0.51 * * *$ & 0.11 & $0.37 * * *$ & \\
\hline Mean & 728 & 4.6 & 0.09 & 3.7 & 0.26 & 0.01 & 0.10 & 0.19 & 42108 & 1.72 & 521 & 0.13 \\
\hline S.D. & 961 & 4.1 & 0.07 & 2.8 & 0.11 & 0.006 & 0.05 & 0.08 & 27209 & 0.41 & 387 & 0.11 \\
\hline
\end{tabular}

a *p $<0.05, * * \mathbf{p}<0.01, * * * p<0.001$ 


\section{Table 4: Negative binomial regression results}

Dependent variable: number of patents in cluster $i$ in industry $k$ and period $t$

\begin{tabular}{|c|c|c|c|c|c|c|c|}
\hline & \multicolumn{4}{|c|}{$\begin{array}{l}\text { Labor-intensive ( } T=1) \text { vs. } \\
\text { knowledge-intensive }(T=0)\end{array}$} & \multicolumn{3}{|c|}{ Emerging $(T=1)$ vs. developed $(T=0)$} \\
\hline & $\begin{array}{c}\text { Benchmark } \\
\text { (1) }\end{array}$ & $\begin{array}{c}\text { International } \\
\text { (2) }\end{array}$ & $\begin{array}{l}\text { Trans-local } \\
\text { (3) }\end{array}$ & $\begin{array}{c}\text { Regional } \\
\text { (4) }\end{array}$ & $\begin{array}{c}\text { International } \\
(5)\end{array}$ & $\begin{array}{c}\text { Trans-local } \\
\text { (6) }\end{array}$ & $\begin{array}{c}\text { Regional } \\
\text { (7) }\end{array}$ \\
\hline Ln(vertical eigen. Centrality) & & $\begin{array}{c}12.137^{* *} \\
(6.932)\end{array}$ & $\begin{array}{l}9.913^{*} \\
(9.897)\end{array}$ & $\begin{array}{l}6.488 \\
(5.914)\end{array}$ & $\begin{array}{c}13.926^{* *} \\
(6.832)\end{array}$ & $\begin{array}{l}8.475^{*} \\
(8.423)\end{array}$ & $\begin{array}{c}4.001 \\
(5.182)\end{array}$ \\
\hline $\operatorname{Ln}($ vertical eigen. Centrality $) * \mathrm{~T}$ & & $\begin{array}{l}63.908 * * * \\
(5.826)\end{array}$ & $\begin{array}{l}52.244 * * * \\
(5.115)\end{array}$ & $\begin{array}{c}17.437 \\
(18.094)\end{array}$ & $\begin{array}{l}65.373 * * * \\
(4.664)\end{array}$ & $\begin{array}{c}54.916 * * * \\
(6.092)\end{array}$ & $\begin{array}{c}10.463 \\
(11.840)\end{array}$ \\
\hline $\operatorname{Ln}$ (horizontal eigen. Centrality) & & $\begin{array}{l}99.462 * * * \\
(5.931)\end{array}$ & $\begin{array}{l}95.009 * * * \\
(5.278)\end{array}$ & $\begin{array}{l}41.096^{*} \\
(37.892)\end{array}$ & $\begin{array}{l}98.741 * * * \\
(6.679)\end{array}$ & $\begin{array}{l}91.328 * * * \\
(5.934)\end{array}$ & $\begin{array}{l}36.175^{*} \\
(35.724)\end{array}$ \\
\hline $\mathrm{Ln}$ (horizontal eigen. Centrality) $* \mathrm{~T}$ & & $\begin{array}{l}-59.786^{*} \\
(59.775)\end{array}$ & $\begin{array}{l}-58.329^{*} \\
(58.317)\end{array}$ & $\begin{array}{l}-30.261^{*} \\
(29.063)\end{array}$ & $\begin{array}{l}-57.882^{*} \\
(57.873)\end{array}$ & $\begin{array}{l}-55.413^{*} \\
(55.410)\end{array}$ & $\begin{array}{l}-32.418^{*} \\
(31.997)\end{array}$ \\
\hline Ln (Intra-firm centrality) & $\begin{array}{l}76.210 * * * \\
(4.995)\end{array}$ & $\begin{array}{l}66.848 * * * \\
(2.914)\end{array}$ & $\begin{array}{c}60.374 * * * \\
(2.028)\end{array}$ & $\begin{array}{l}34.848^{*} \\
(33.971)\end{array}$ & $\begin{array}{l}63.684 * * * \\
(2.108)\end{array}$ & $\begin{array}{c}61.005^{* * *} \\
(2.009)\end{array}$ & $\begin{array}{l}30.005^{*} \\
(28.182)\end{array}$ \\
\hline $\operatorname{Ln}$ (local buyer-supplier linkages) & $\begin{array}{l}12.947 \\
(2.981)\end{array}$ & $\begin{array}{c}11.620 \\
(11.684)\end{array}$ & $\begin{array}{c}11.590 \\
(11.693)\end{array}$ & $\begin{array}{c}10.449 \\
(11.941)\end{array}$ & $\begin{array}{c}10.962 \\
(10.995)\end{array}$ & $\begin{array}{c}10.851 \\
(10.857)\end{array}$ & $\begin{array}{c}10.626 \\
(10.918)\end{array}$ \\
\hline $\operatorname{Ln}$ (local intra-firm linkages) & $\begin{array}{l}18.791^{* *} \\
(9.465)\end{array}$ & $\begin{array}{l}17.915^{*} \\
(17.903)\end{array}$ & $\begin{array}{l}17.605^{*} \\
(17.601)\end{array}$ & $\begin{array}{l}20.007^{*} \\
(19.284)\end{array}$ & $\begin{array}{l}16.985^{*} \\
(16.970)\end{array}$ & $\begin{array}{l}16.432 * \\
(16.406)\end{array}$ & $\begin{array}{l}18.374 * \\
(18.951)\end{array}$ \\
\hline Ln(local partnership linkages) & $\begin{array}{l}49.905^{* * *} \\
(4.002)\end{array}$ & $\begin{array}{l}45.258^{* * *} \\
(3.175)\end{array}$ & $\begin{array}{l}41.376^{* * *} \\
(3.784)\end{array}$ & $\begin{array}{c}40.360^{* * *} \\
(2.119)\end{array}$ & $\begin{array}{l}44.001 * * * \\
(3.995)\end{array}$ & $\begin{array}{l}40.039 * * * \\
(3.094)\end{array}$ & $\begin{array}{l}33.188^{* * *} \\
(2.001)\end{array}$ \\
\hline Ln(cluster density) & $\begin{array}{l}40.012 * * * \\
(3.393)\end{array}$ & $\begin{array}{l}35.001 * \\
(11.989)\end{array}$ & $\begin{array}{c}35.593 * * \\
(12.007)\end{array}$ & $\begin{array}{l}35.001^{*} \\
(20.543)\end{array}$ & $\begin{array}{l}34.278^{*} \\
(12.233)\end{array}$ & $\begin{array}{c}33.496 * * \\
(11.593)\end{array}$ & $\begin{array}{c}31.949 * * \\
(10.131)\end{array}$ \\
\hline Ln(wages) & $\begin{array}{c}16.493 \\
(16.557)\end{array}$ & $\begin{array}{c}28.473 \\
(28.502)\end{array}$ & $\begin{array}{c}20.218 \\
(20.309)\end{array}$ & $\begin{array}{c}22.147 \\
(26.392)\end{array}$ & $\begin{array}{c}23.743 \\
(23.802)\end{array}$ & $\begin{array}{c}17.887 \\
(18.005)\end{array}$ & $\begin{array}{c}15.094 \\
(17.925)\end{array}$ \\
\hline Ln(location quotient) & $\begin{array}{l}109.532 * * * \\
(10.638)\end{array}$ & $\begin{array}{c}103.284 * * \\
(40.067)\end{array}$ & $\begin{array}{c}106.614 * * \\
(40.115)\end{array}$ & $\begin{array}{c}114.577^{* *} \\
(43.805)\end{array}$ & $\begin{array}{c}101.285^{* *} \\
(40.007)\end{array}$ & $\begin{array}{c}102.614^{* *} \\
(41.969)\end{array}$ & $\begin{array}{c}112.476^{* *} \\
(42.916)\end{array}$ \\
\hline $\operatorname{Ln}(\mathrm{R} \& \mathrm{D}$ investments) & $\begin{array}{l}179.945^{* * *} \\
(15.016)\end{array}$ & $\begin{array}{c}153.371 * * * \\
(11.395)\end{array}$ & $\begin{array}{c}155.937 * * * \\
(11.862)\end{array}$ & $\begin{array}{c}171.035^{* * *} \\
(12.076)\end{array}$ & $\begin{array}{c}154.372 * * * \\
(10.839)\end{array}$ & $\begin{array}{c}158.025 * * * \\
(11.072)\end{array}$ & $\begin{array}{c}182.830 * * * \\
(13.006)\end{array}$ \\
\hline Labor force education & $\begin{array}{l}1.793 * * * \\
(0.119)\end{array}$ & $\begin{array}{c}1.703 * * * \\
(0.112)\end{array}$ & $\begin{array}{c}1.882 * * * \\
(0.127)\end{array}$ & $\begin{array}{c}2.954 * * * \\
(0.382)\end{array}$ & $\begin{array}{c}1.503 * * * \\
(0.164)\end{array}$ & $\begin{array}{c}1.936^{* * * *} \\
(0.185)\end{array}$ & $\begin{array}{c}3.007 * * * \\
(0.399)\end{array}$ \\
\hline Industry dummies & Yes & Yes & Yes & Yes & Yes & Yes & Yes \\
\hline Location dummies & Yes & Yes & Yes & Yes & Yes & Yes & Yes \\
\hline Period dummies & Yes & Yes & Yes & Yes & Yes & Yes & Yes \\
\hline $\bar{N}$ & 446 & 446 & 446 & 446 & 446 & 446 & 446 \\
\hline chi2 & $358.25^{* * *}$ & $388.07 * * *$ & $392.58 * * *$ & $389.12 * * *$ & $391.12 * * *$ & $394.09 * * *$ & $395.27 * * *$ \\
\hline Log likelihood & -672.57 & -643.82 & -645.69 & -644.95 & -646.81 & -649.94 & -651.98 \\
\hline LR chi2 & 48.39 & 31.85 & 34.03 & 32.39 & 35.93 & 37.27 & 38.45 \\
\hline
\end{tabular}

Notes: Coefficients are reported with errors that include eigenvector terms based on the weighted residuals to adjust for spatial autocorrelation. ${ }^{* *},{ }^{* *}$, and $*$ denote significance at the $1 \%, 5 \%$ and $10 \%$ levels, respectively. Coefficients on constant, location, industry and period dummies are not reported. We categorized labor-intensive clusters as those with a horizontal eigenvector centrality smaller than 0.35 , and knowledge-intensive clusters as those with a horizontal eigenvector centrality larger than 0.35 . 
Table 5: Negative binomial regression results, lagged independent variables

Dependent variable: number of patents in cluster $i$ in industry $k$ and period $t$

\begin{tabular}{|c|c|c|c|c|c|c|}
\hline & \multicolumn{3}{|c|}{$\begin{array}{l}\text { Labor-intensive ( } T=1) \text { vs. } \\
\text { knowledge-intensive }(T=0)\end{array}$} & \multicolumn{3}{|c|}{ Emerging $(T=1)$ vs. developed $(T=0)$} \\
\hline & International & Trans-local & Regional & International & Trans-local & Regional \\
\hline & (1) & (2) & (3) & (4) & (5) & (6) \\
\hline Ln(vertical eigen. Centrality) & $\begin{array}{l}9.005^{*} \\
(7.178)\end{array}$ & $\begin{array}{l}4.284^{*} \\
(4.197)\end{array}$ & $\begin{array}{c}5.002 \\
(5.894)\end{array}$ & $\begin{array}{l}8.107^{*} \\
(7.915)\end{array}$ & $\begin{array}{l}4.481 * \\
(4.415)\end{array}$ & $\begin{array}{c}4.931 \\
(5.612)\end{array}$ \\
\hline $\operatorname{Ln}($ vertical eigen. Centrality) $* \mathrm{~T}$ & $\begin{array}{l}84.701^{*} \\
(79.193)\end{array}$ & $\begin{array}{l}81.612^{*} \\
(80.815)\end{array}$ & $\begin{array}{c}15.019 \\
(17.815)\end{array}$ & $\begin{array}{l}81.001 * \\
(80.356)\end{array}$ & $\begin{array}{l}80.927^{*} \\
(80.004)\end{array}$ & $\begin{array}{c}14.773 \\
(16.284)\end{array}$ \\
\hline Ln(horizontal eigen. Centrality) & $\begin{array}{l}103.205^{* * *} \\
(8.873)\end{array}$ & $\begin{array}{l}99.003 * * * \\
(8.235)\end{array}$ & $\begin{array}{l}31.293 * \\
(28.684)\end{array}$ & $\begin{array}{l}96.709 * * * \\
(7.814)\end{array}$ & $\begin{array}{l}91.827 * * * \\
(7.113)\end{array}$ & $\begin{array}{l}29.035^{*} \\
(27.646)\end{array}$ \\
\hline Ln(horizontal eigen. Centrality) $* \mathrm{~T}$ & $\begin{array}{l}-64.684^{*} \\
(64.652)\end{array}$ & $\begin{array}{l}-69.725^{*} \\
(69.720)\end{array}$ & $\begin{array}{l}-28.856^{*} \\
(26.948)\end{array}$ & $\begin{array}{l}-62.108^{*} \\
(62.102)\end{array}$ & $\begin{array}{l}-65.866^{*} \\
(65.721)\end{array}$ & $\begin{array}{l}-27.132^{*} \\
(25.118)\end{array}$ \\
\hline Ln (Intra- & $\begin{array}{l}78.276^{* *} \\
(33.926)\end{array}$ & $\begin{array}{l}73.328^{*} \\
(65.147)\end{array}$ & $\begin{array}{l}62.911^{*} \\
(53.290)\end{array}$ & $\begin{array}{l}74.466^{* *} \\
(33.293)\end{array}$ & $\begin{array}{l}71.394 * \\
(63.112)\end{array}$ & $\begin{array}{l}60.934 * \\
(52.927)\end{array}$ \\
\hline Ln(local buyer-supplier linkages) & $\begin{array}{c}12.028 \\
(12.033)\end{array}$ & $\begin{array}{c}12.682 \\
(12.690)\end{array}$ & $\begin{array}{c}6.374 \\
(7.023)\end{array}$ & $\begin{array}{c}16.216 \\
(16.234)\end{array}$ & $\begin{array}{c}13.743 \\
(13.822)\end{array}$ & $\begin{array}{l}6.125 \\
(6.993)\end{array}$ \\
\hline Ln(local intra-firm linkages) & $\begin{array}{l}42.813 * * \\
(18.752)\end{array}$ & $\begin{array}{l}49.016^{* *} \\
(19.547)\end{array}$ & $\begin{array}{l}31.365^{*} \\
(28.047)\end{array}$ & $\begin{array}{l}40.116^{* *} \\
(18.164)\end{array}$ & $\begin{array}{l}43.109 * * \\
(19.203)\end{array}$ & $\begin{array}{l}31.369^{*} \\
(28.051)\end{array}$ \\
\hline Ln(local partnership linkages) & $\begin{array}{l}66.265^{* * *} \\
(4.214)\end{array}$ & $\begin{array}{c}64.347 * * * \\
(4.012)\end{array}$ & $\begin{array}{c}72.843 * * * \\
(5.016)\end{array}$ & \begin{tabular}{|l}
$68.254 * * *$ \\
$(4.911)$
\end{tabular} & $\begin{array}{l}66.832 * * * \\
(4.815)\end{array}$ & $\begin{array}{l}73.066^{* * * *} \\
(5.212)\end{array}$ \\
\hline Ln(cluster density) & $\begin{array}{l}77.043^{*} \\
(76.517)\end{array}$ & $\begin{array}{l}76.069^{*} \\
(75.135)\end{array}$ & $\begin{array}{l}80.342 * \\
(79.758)\end{array}$ & $\begin{array}{l}75.012 * \\
(74.219)\end{array}$ & $\begin{array}{l}73.750^{*} \\
(73.534)\end{array}$ & $\begin{array}{l}81.007 * \\
(80.584)\end{array}$ \\
\hline Ln(wages) & $\begin{array}{c}21.418 \\
(22.005)\end{array}$ & $\begin{array}{c}18.557 \\
(20.611)\end{array}$ & $\begin{array}{c}24.937 \\
(26.261)\end{array}$ & $\begin{array}{c}29.408 \\
(30.409)\end{array}$ & $\begin{array}{c}25.612 \\
(26.438)\end{array}$ & $\begin{array}{c}25.014 \\
(26.617)\end{array}$ \\
\hline $\operatorname{Ln}$ (location quotient) & $\begin{array}{c}115.348^{* * *} \\
(16.017)\end{array}$ & $\begin{array}{c}113.519^{* * * *} \\
(16.206)\end{array}$ & $\begin{array}{c}113.995^{*} \\
(85.385)\end{array}$ & $\begin{array}{c}112.251^{* * *} \\
(15.023)\end{array}$ & $\begin{array}{c}110.334 * * * \\
(15.219)\end{array}$ & $\begin{array}{c}113.981^{*} \\
(85.336)\end{array}$ \\
\hline $\operatorname{Ln}(\mathrm{R} \& \mathrm{D}$ investments) & $\begin{array}{c}171.782^{* * *} \\
(14.008)\end{array}$ & $\begin{array}{c}162.305^{* * *} \\
(12.105)\end{array}$ & $\begin{array}{c}193.867 * * * \\
(16.442)\end{array}$ & $\begin{array}{c}177.341 * * * \\
(14.828)\end{array}$ & $\begin{array}{c}165.291 * * * \\
(13.994)\end{array}$ & $\begin{array}{c}194.552^{* * *} \\
(16.998)\end{array}$ \\
\hline Labor force education & $\begin{array}{c}1.781 * * * \\
(0.113) \\
\end{array}$ & $\begin{array}{c}1.546^{* * * *} \\
(0.108)\end{array}$ & $\begin{array}{c}3.362^{* * *} \\
(0.396)\end{array}$ & $\begin{array}{c}1.903 * * * \\
(0.127) \\
\end{array}$ & $\begin{array}{c}1.901 * * * \\
(0.126) \\
\end{array}$ & $\begin{array}{c}3.425^{* * *} \\
(0.401)\end{array}$ \\
\hline Industry dummies & Yes & Yes & Yes & Yes & Yes & Yes \\
\hline $\mathrm{N}$ & 290 & 290 & 290 & 290 & 290 & 290 \\
\hline chi2 & $621.88^{*}$ & $624.56^{*}$ & $629.81^{*}$ & $629.39^{*}$ & $631.71^{*}$ & $636.03^{*}$ \\
\hline Log likelihood & -1143.45 & -1145.89 & -1148.89 & -1165.82 & -1168.58 & -1171.94 \\
\hline LR chi2 & 73.97 & 77.01 & 79.53 & 77.31 & 82.30 & 83.56 \\
\hline
\end{tabular}

Notes: Coefficients are reported with errors that include eigenvector terms based on the weighted residuals to adjust for spatial autocorrelation. $* * *, * *$, and $*$ denote significance at the $1 \%, 5 \%$ and $10 \%$ levels, respectively. Coefficients on constant and industry dummies are not reported. We categorized laborintensive clusters as those with a horizontal eigenvector centrality smaller than 0.35 , and knowledgeintensive clusters as those with a horizontal eigenvector centrality larger than 0.35 . 


\section{Appendix: Random effects approach to panel data for reverse causality test with centrality as dependent variable}

Ln(horizontal eigenvector centrality)

\begin{tabular}{|c|c|c|c|c|c|c|}
\hline & \multicolumn{3}{|c|}{$\begin{array}{l}\text { Labor-intensive }(T=1) \text { vs. } \\
\text { knowledge-intensive }(T=0)\end{array}$} & \multicolumn{3}{|c|}{ Emerging $(T=1)$ vs. developed $(T=0)$} \\
\hline & International & Trans-local & Regional & International & Trans-local & Regional \\
\hline & (1) & (2) & (3) & (4) & (5) & (6) \\
\hline Number of patents & $\begin{array}{c}0.0006 \\
(0.0008)\end{array}$ & $\begin{array}{c}0.0004 \\
(0.0005)\end{array}$ & $\begin{array}{c}0.0002 \\
(0.0004)\end{array}$ & $\begin{array}{l}0.0005^{*} \\
(0.0005)\end{array}$ & $\begin{array}{c}0.0002 \\
(0.0004)\end{array}$ & $\begin{array}{c}0.0001 \\
(0.0002)\end{array}$ \\
\hline Number of patents $* \mathrm{~T}$ & $\begin{array}{l}-0.009 \\
(0.010)\end{array}$ & $\begin{array}{l}-0.008 \\
(0.009)\end{array}$ & $\begin{array}{c}-0.006 \\
(0.008)\end{array}$ & $\begin{array}{l}-0.005 \\
(0.007)\end{array}$ & $\begin{array}{l}-0.004 \\
(0.005)\end{array}$ & $\begin{array}{l}-0.002 \\
(0.003)\end{array}$ \\
\hline $\mathrm{N}$ & 446 & 446 & 446 & 446 & 446 & 446 \\
\hline R-squared within & 0.16 & 0.15 & 0.12 & 0.15 & 0.13 & 0.11 \\
\hline R-squared between & 0.23 & 0.20 & 0.17 & 0.20 & 0.18 & 0.15 \\
\hline R-squared overall & 0.20 & 0.18 & 0.14 & 0.17 & 0.15 & 0.13 \\
\hline Prob $>$ chi 2 & 0.0001 & 0.0003 & 0.0004 & 0.0003 & 0.0005 & 0.0007 \\
\hline & \multicolumn{6}{|c|}{ Ln(vertical eigenvector Centrality) } \\
\hline & (7) & (8) & (9) & (10) & (11) & (12) \\
\hline Number of patents & $\begin{array}{c}0.0001 \\
(0.0002)\end{array}$ & $\begin{array}{l}0.00009 \\
(0.0001)\end{array}$ & $\begin{array}{c}0.00007 \\
(0.00008)\end{array}$ & $\begin{array}{l}0.00008 \\
(0.0001)\end{array}$ & $\begin{array}{c}0.00005 \\
(0.00007)\end{array}$ & $\begin{array}{c}0.00004 \\
(0.00006)\end{array}$ \\
\hline Number of patents $* \mathrm{~T}$ & $\begin{array}{l}0.009 \\
(0.01)\end{array}$ & $\begin{array}{c}0.005 \\
(0.006)\end{array}$ & $\begin{array}{c}0.002 \\
(0.004)\end{array}$ & $\begin{array}{c}0.007 \\
(0.008)\end{array}$ & $\begin{array}{c}0.006 \\
(0.007)\end{array}$ & $\begin{array}{c}0.001 \\
(0.003)\end{array}$ \\
\hline $\mathrm{N}$ & 446 & 446 & 446 & 446 & 446 & 446 \\
\hline R-squared within & 0.11 & 0.09 & 0.08 & 0.08 & 0.06 & 0.05 \\
\hline R-squared between & 0.15 & 0.14 & 0.12 & 0.13 & 0.11 & 0.09 \\
\hline R-squared overall & 0.13 & 0.11 & 0.10 & 0.11 & 0.09 & 0.07 \\
\hline Prob $>$ chi 2 & 0.0006 & 0.0008 & 0.0009 & 0.001 & 0.001 & 0.002 \\
\hline
\end{tabular}

Notes: $* * *, * *$, and $*$ denote significance at the $1 \%, 5 \%$ and $10 \%$ levels, respectively. For brevity we present only the coefficients of the two key independent variables. The coefficients on the location dummies, industry dummies, constant and control variables are not reported. We categorized laborintensive clusters as those with a horizontal eigenvector centrality smaller than 0.35 , and knowledgeintensive clusters as those with a horizontal eigenvector centrality larger than 0.35 . 
Figure 1: Multiplex embeddedness and cluster archetypes

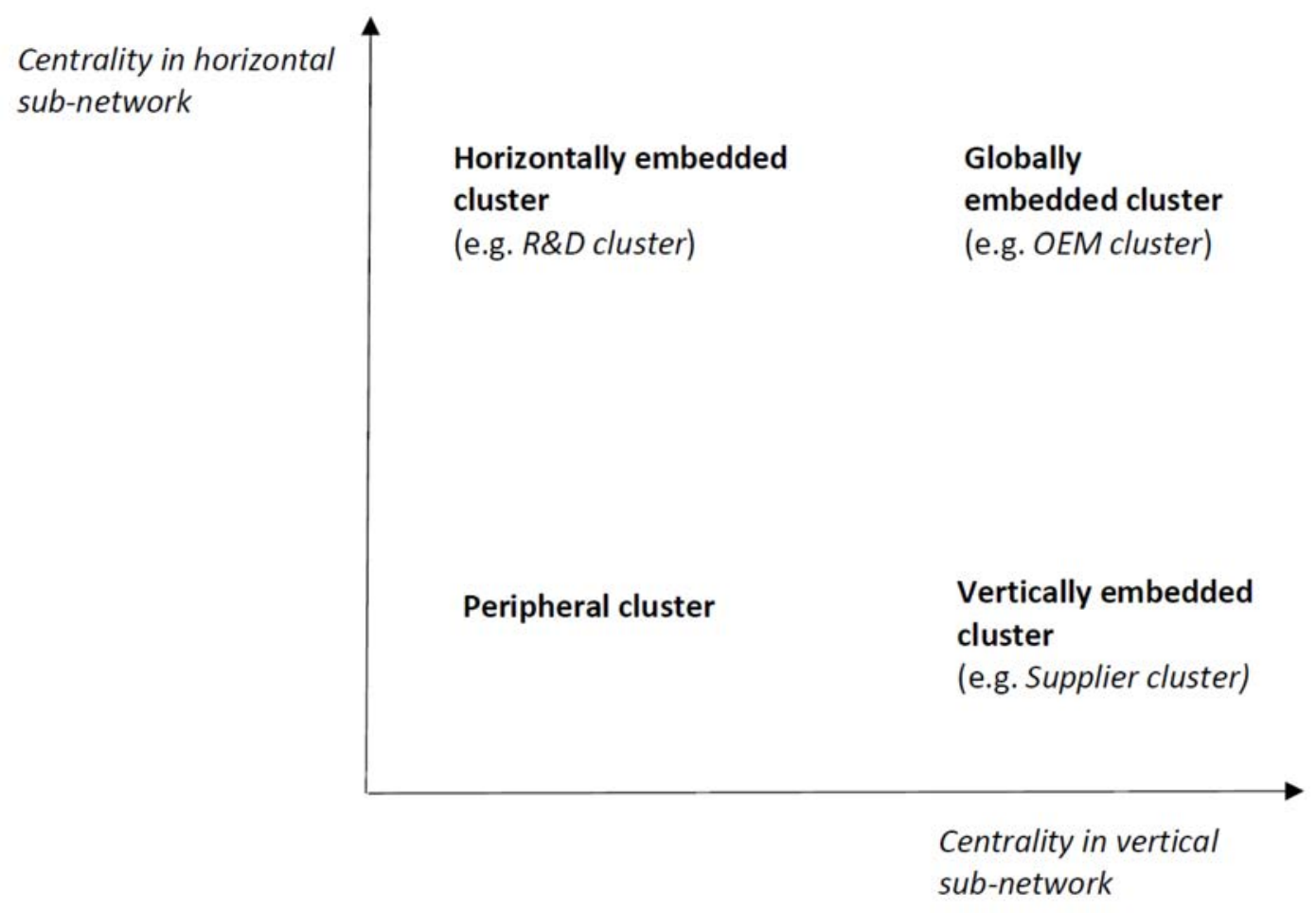


Figure 2: Cluster archetype identification, 2010-2014

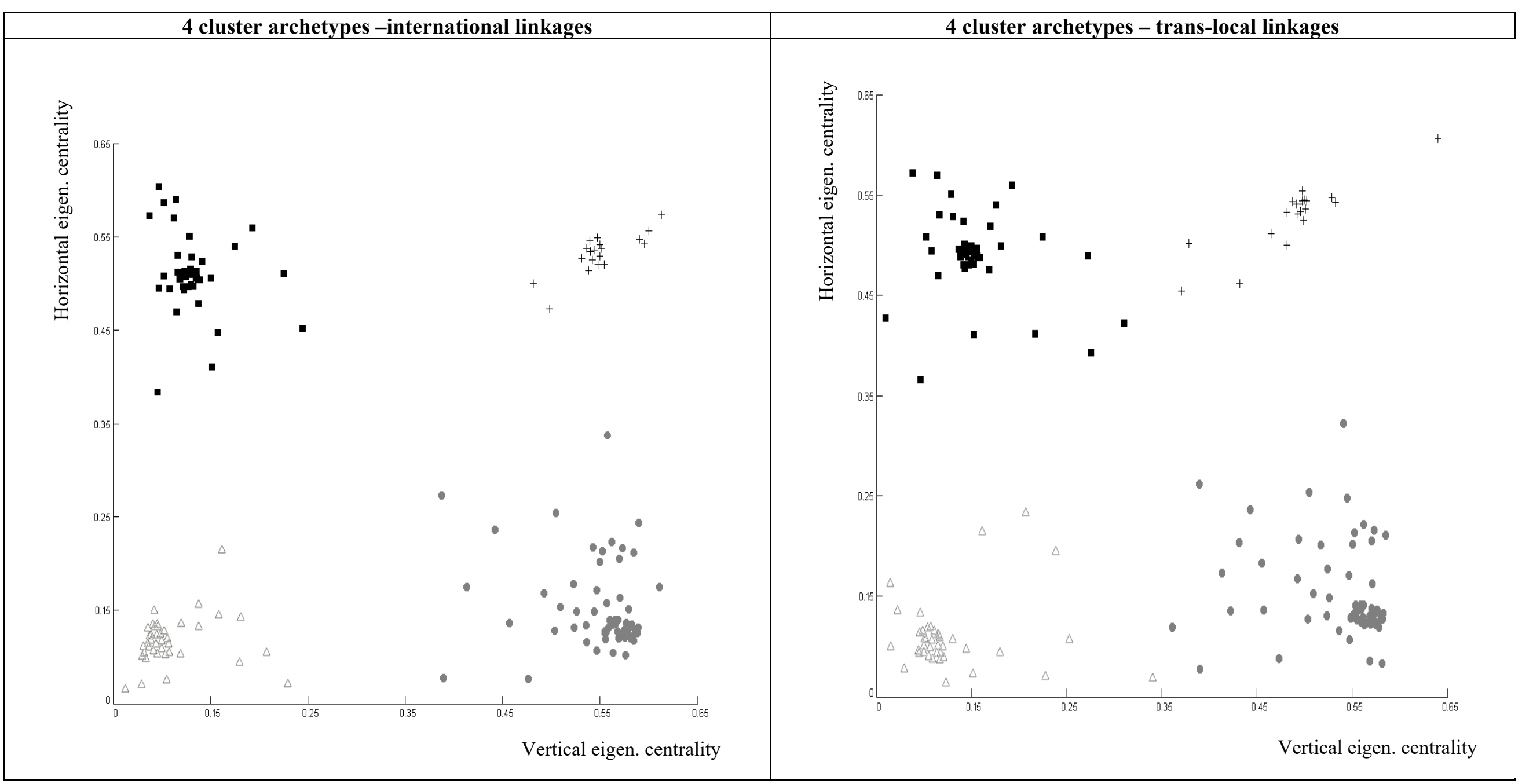

